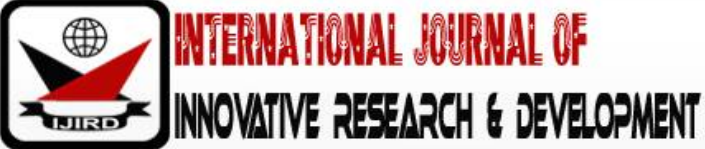

ISSN 2278 - 0211 (Online)

\section{Kidnapping and Abduction in Nigeria: Threat to National Security and Socioeconomic Development}

\author{
Dr. Timothy Gwami Ishaya \\ Lecturer, Department of Theological Studies / Christian Education, \\ Agape Christian Theological Seminary, Abuja, Nigeria \\ Ubong Aniema James \\ Student, Department of Theological Studies, \\ Agape Christian Theological Seminary Abuja, Nigeria \\ Gadu, Ezekiel \\ Student, Department of Theological Studies \\ Agape Christian Theological Seminary Abuja, Nigeria
}

\begin{abstract}
:
The phenomenon of kidnapping and abduction is on the increase on daily basis in Nigeria, and the increasing rate has become very worrisome and notorious in the ears of everyone to both the citizens and foreigners alike in Nigeria. In Nigeria, kidnapping is often done for ransom and it occurs mainly for economic and political reasons. Kidnapping and abduction involves taking away of a person or persons against the person's will, usually to hold the person in confinement without legal authority. Kidnapping started in the Niger Delta region in 1999, while kidnapping and abduction for ransom became prevalent as from 2006. It was strategically used to wage the resource control war against the Federal Government and the multi-national oil companies. The militants had justified their kidnapping and oil bunkering activities as a means of drumming-home the Niger Delta demands to the then recalcitrant Nigerian government. Today it is spreading like wild fire into all the six(6) geo-political zones (both southern and northern states of Nigeria). More than 95 percent of all kidnappings and abductions in Nigeria have occurred in the south-east and Niger Delta regions. However, with the implementation of the Amnesty Programme since 2009, there has been increase in cases of kidnapping and abduction instead of reducing. While the perpetrators now involve both members and non-members of armed groups, the victims also include expatriates and indigenes of the region depending on their economic worth as it is used as a means of livelihood and survival by people indulging in it in post-amnesty Niger Delta. Most of the hostages or victims are released unharmed after payment of ransom. Kidnapping and abduction for any reason is a crime against humanity, it reduces man into the semblance of an animal. It has created insecurity, threat to National Security and adverse effect on socioeconomic development in Nigeria. This paper examines the phenomenon of kidnapping and abduction in Nigeria with a view to underscore its threat to national security and socioeconomic development. This is against the backdrop of the rising incidence and prevalence of the crime in contemporary Nigeria. By way of qualitative analysis, predicated on secondary sources of data obtained from various books, journals, seminar papers, lectures, newspapers and magazines, the paper posits that kidnapping has been motivated and sustained by criminal quest for material accumulation. The paper adds that the situation has been compounded by the growing trend of criminal impunity in Nigeria wherefore the government's capacity to sanction and deter crime is abysmal. The paper observes that kidnapping portends dangerously for Nigeria's national security and socioeconomic in view of its untoward impacts and implications. This paper focuses on examining the act and issue of kidnapping from its earliest encounter, its nature, its causes, its effect on victims and the Nigerian society at large, and a closer look at the major social and economic factors responsible for kidnapping in Nigeria. The paper submits that crimes like kidnapping and abduction would continue to prevail in Nigeria until pragmatic measures are taken to deter their occurrence as well as penalize their commission. The paper argues that widespread increase in kidnapping and abduction in Nigeria can be traced to prevalence of poverty and unemployment, and it recommended massive job creation and reconsideration of the system of justice administration in the country as solutions to the problem of widespread kidnapping and abduction in Nigeria.
\end{abstract}

Keywords: Kidnapping, abduction, national security, socio-economic development

\section{Introduction}

Kidnapping and abduction for ransom is a common occurrence in various parts of the world today such as: Baghdad. Mexico, Colombia, Haiti, Brazil, Philippines, parts of former Soviet Union, Sudan and South Africa. Kidnapping and abduction is a serious problem which is being faced in Nigeria every day. It has now become a regular thing to hear 
news about the abduction of people in the country; one of the biggest case was the one which brought up the "Bring Back Our Girls" campaign - it was the time when the whole world heard about the problems in Nigeria. It has become an alarming phenomenon of great concern in Nigeria that has qualified the entity Nigeria a failing of failed state. Appropriately enough, kidnapper seems to have originated among those who perpetrate crime.

The word kidnapper is derived from kid and napper, the two parts of the compound, were slang of the sort that criminals used. Kid, which still has an informal air, was considered low slang when kidnapper was formed, and napper is obsolete slang for a thief, coming from the verb nap, "to steal." Nap is possibly a variant of nab, which also still has a slangy ring. In 1678, the year in which the word is first recorded, kidnappers plied their trade to secure labourers for plantations in colonies such as the ones in North America. The term later took on the broader sense that it has today. The verb kidnap is recorded later (1682) than the noun and so is possibly a back-formation, that is, people may have assumed that a kidnapper kidnaps. Kidnapping and abduction is the act of seizing and detaining or carrying away a person by unlawful force or by fraud, and often with a demand for ransom. For an act to be deemed kidnapping, it must involve coercive movement of a victim from one place to another, detention or seizure of that person be it a child or an adult. It is usually motivated by financial gain or political benefit. Thus, opportunist or regular criminals as well as political opponents can resort to kidnapping in order to illegally obtain economic benefits or have their demands granted. In many cases, kidnapping and abduction is a 'business' involving a demand for ransom which may vary considerably, depending on the victim's personal status. Kidnapping and abduction is on the increase in Nigeria. There are more than 1,000 kidnapping and abduction incidents reported in a year, and there are undoubtedly many that are unreported. Kidnapping and abduction remains one of the elements of militancy in the Niger Delta in Nigeria. It started in the Niger Delta region due to the activities of militant groups because of resource struggle, and environmental damage occasioned by crude oil exploration in the area. Today, from the Niger Delta region, it has spread to all regions of Nigeria. It incidence has also increased with the emergence of 'Boko Haram' terrorism in the North-eastern Nigeria. Kidnapping in Nigeria is usually for either financial or political benefit. Victims were originally foreign oil workers, but today many are locals, often employees of international oil and oil service companies, and not necessarily wealthy; anyone whose family might pay a ransom can be targeted. Some of the reasons behind kidnapping in Nigeria are poverty, corruption, political intimidation; whereas some of the effects of kidnapping include financial victimization, rape, physical violence, and even murder of the victim. In order to address the problem of kidnapping in Nigeria, there is need to reduce poverty, unemployment and corruption.

The first act of kidnapping and abduction in Nigeria started 2006 when the militants of the Niger Delta took total hostage to protest the inequality in the region. According to the militants, Nigeria is built at the expense of the region which serves as the cash cow for the whole country. The action which started from the kidnapping of government expatriates has moved to men of God and their children, Nigerian politicians and their children, and religious leaders. Reuters (2009) pointed out that a total of 512 kidnapping cases have been reported so far this year, up from 353 for all of 2008. Initially it was used by the Niger Delta militants, to make a case for the development of the region. At the initial stage according to Aloysius Okorie the Commissioner of Police of Imo State, they were not asking for ransom. But later on the militant, hoodlums and criminals hijacked it and started kidnapping for a ransom (News Watch, June 29, 2009 P.16).

Virtually, all of the kidnappings occurred in the south-east and Niger Delta regions, which harbour the Africa's biggest oil and gas industry. Most of the hostages are released unharmed after payment of ransom. South-Eastern Nigeria (Abia State) in particular had most incidents with 110 people taken hostage; all of them have been released while police have arrested 70 suspects in connection with the kidnapping. Gangs have taken advantage of the breakdown in law and order to target any high profile expatriate or Nigerian that could provide them with a large ransom.

One of the fore most recorded cases of kidnapping was when the Movement for the Emancipation of the Niger Delta (MEND) kidnapped nine (9) foreign workers in Delta State to bargain for the release of detained Mujahid Asari Dokubo, Leader of the Niger Delta People Volunteer Force, (NDPVF) and the arrowhead of the Niger Delta Struggle, for a fair deal in this cycle. They did not ask for ransom, only that their leader should be released in exchange for the hostages. The federal government dangled irresistible carrot-money (hard Currency), the boys could not resist it, and so they took the money and released the hostages (Tell, December 17, 2007, P23). Initially, expatriate oil workers and a few of their unfortunate indigenous colleagues were the targets. But within the '18 months that Dokubo languished in the State Security Service, (SSS's) Underground gulag at Abuja, hostage taking not only prospered, it gained considerable leverage and displaced armed robbery as the highest paying crime in the Niger Delta.

In addition, after the April elections, kidnapping became a business tool to settle grievances by groups who felt short-changed by politicians they worked for (Tell, December 17, 2007, p.24). Today, it is spreading like wildfire into the neighbouring South East where some Igbo youths, initially masquerading as members of the Movement for the Actualizations of the Sovereign State of Biafra (MASSOB), fighting for the release of their leader, Ralph Uwazuruike, who like Dokubo, was locked up by the State for their activities. In the South East, kidnapping is very prevalent in Abia, Imo, and Anambra States. It extended to Akwa Ibom State.

The pervasive insecurity created by kidnapping and abduction "activities is a key manifestation of the breach of social contract by the Nigeria government and a consequent manifestation of frustration aggressions depositions amongst the people. Nigeria is drifting towards the Hobbesian social contract where citizens opt out of the social contract due to one party (the state) increasingly failing to keep its own side of the bargain. This is a manifestation of a 'failed state'. This is a State which has become incapable of fulfilling the basic functions of a Sovereign government. These functions include physical control of its territory, Provision of Security of life and Property for it Citizens, the monopoly of the use of Legitimate physical force and ability to provide reasonable public services or to interact with other States as a full member of the international community. 
A" failing State" denotes State in transition to a failed State. Here while the state remains nominally a Sovereign and fulfils a modicum of the functions of a Sovereign government, the central government has become so weak and ineffective that it has little practical control over much of its territory, leading to an upsurge in pervasive insecurity such as kidnapping, Organized assassinations and robberies. A failing state is also characterized by a weakened ability to provide basic public services and widespread Corruption as people think of themselves first, following the failure of the state to perform its traditional functions, most of the countries in the developing world involved in civil wars or protracted internal conflicts could qualify as ' failing states.

In Anambra State, kidnapping started long before it creped to Imo state. It is very noticeable that kidnap victims are easily rescued and the kidnappers arrested in most of the kidnap cases in the south east. This can be attributed to the terrain of their operation. They operate within land locations; they either keep their victims in the forest or secluded residential houses within a community. It is not so in the core South or Niger Delta such as Delta Ijaw, Bayelsa and Rivers State. Here once one is kidnapped, he is whisked to the creek where, the police cannot operate effectively. Hence, kidnap victims are hardly rescued nor the kidnappers arrested due to the terrain.

Kidnapping and abduction is often used by armed groups especially terror inclined groups as tactics to force significant concessions relating to their demands on their primary targets. The crises in the Niger Delta have made the region prone to armed conflict and violent crimes where series of terror-related violence such as deliberate attacks against government installations, piracy, oil bunkering, kidnapping and abduction (hostage taking) among others are recorded on daily basis. One of the most protracted criminal violence in the Niger Delta region is kidnapping and abduction

Kidnapping and abduction have assumed a business status for criminals who kidnap for ransom. This has remained one of the greatest drawbacks to investment in Nigeria. Today, social vices in the form of armed robbery, murder, assassination and lately kidnapping and abduction have assumed a frightening proportion; thus, hindering productivity. Though investors had always found the Nigerian business environment suffocating, kidnapping capped it all and made investing in the country both discouraging and unattractive. Due to kidnapping and abduction in Nigeria, factories are closing up, people no longer visit their villages, and socio-economic activities are grinding to a halt.

The socioeconomic implication of kidnapping in Nigeria is that investors will not come because of the insecurity arising from kidnapping, and it has a spiral effect on businesses. So, when such investors keep away from Nigeria, the Nigerian economy is being affected. In the case of kidnapping and abduction the victims are held in a secret location away from public knowledge, whereas in hostage-taking, the victims may be visible and their where about known but rescuing them is difficult so as not to cause collateral damage. However, no significant different exists between the two with regard to stages involved and their motivation and logic. A successful kidnapping incident may involve six stages which commence with strategic planning by the perpetrators, abduction, and concealment, followed by negotiation. After an agreement is struck, the resolution sets in and this may mark the termination of the kidnapping episode. However, further action may be taken by the kidnappers, the victim or government.

In January 2012, kidnappers abducted a US citizen from his vehicle in the Delta and killed his security guard. In April 2012, criminals kidnapped a US national in Imo State and a Spanish citizen in Enugu State in separate incidents. In May 2012, criminals kidnapped an Italian national in Kwara State. On the 7 May a Lebanese national was kidnapped in Kaduna State and his Lebanese colleague was mercilessly killed during the abduction. More on the kidnapping incidences in Nigeria, it was also reported that two engineers (one British and one Italian) were killed by their captors in March 2012 when Nigerian security forces, with support from Britain, attempted to rescue them. They had been held by elements of the Islamic fundamentalist group Boko Haram for ten months.

Aside from Niger Delta militants, Boko Haram members equally kidnap foreign nationals for ransom. On 14th April, 2014 the sect kidnapped 250 female students from Government Girl's Secondary School Chibok in Borno State. Boko Haram kidnappings in Nigeria targeted Western nationals, Christians and government officials. It is active in the northern states, primarily Kano, Katsina, Yobe, Bauchi and Borno. In February 2018, approximately four years after the 2014 Chibok abduction, in the nearby town of Dapchi in Yobe state again another 110 schoolgirls were abducted by Boko Haram, with no government intervention intercepting the abductors yet as of 4 March 2018 A UNICEF report released in April 2018, claimed that more than 1,000 children have been abducted by Boko Haram since 2013.

\section{Conceptual Framew ork}

\subsection{Abduction}

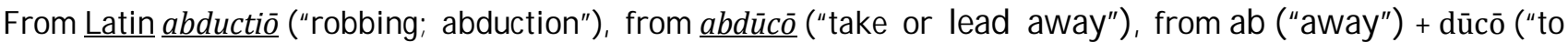
lead"). Abduction is when someone uses deceit or force in order to take a person or a child away from their home or relatives. The abductors do not reveal their motive for taking away the person or the child. Merriam Webster defines 'abduction' as, "to seize and take away (as a person) by force."

\subsection{Kidnapping}

It is the taking away of a person against the person's will, usually to hold the person in false imprisonment, a confinement without legal authority. This may be done for ransom or in furtherance of another crime. Kidnapping (Adibe, 2008) the taking away of a person against the person's will, usually for ransom or in furtherance of another crime. Thus, the following kinds of kidnappings : 


\subsubsection{Economic Kidnapping}

Economic kidnapping or the Kidnapping business is where a financial demand is made, which could be either hard cash, or some other financial resource.

\subsubsection{Political kidnapping}

Political kidnapping on the other hand, is where political concessions such as the release of prisoner, changes to the law and policy retreats, are demanded (Briggs, 2009).

\subsection{National Security}

National security means peace and stability in the community. The concept would seem to relate to measures enacted with a view to safeguarding territorial integrity and national independence from any external threat. It covers any activity prejudicial to the very existence of the State. Nevertheless, this requirement should not be used as a pretext for imposing arbitrary limitations or restrictions on the exercise of human right and freedoms" (United Nations publication "Freedom of the Individual under Law: an Analysis of Article 29 of the United Nations Declaration of Human Rights"). National security is concerned with ensuring state legal codes are not transgressed, and prevention of attacks on public infrastructures and their personnel by implementing civil defence and emergency preparedness measures (including antiterrorism legislation), and ensuring the resilience and redundancy of critical infrastructure. This also includes using counterintelligence services or secret services to protect the nation from internal threats sponsored from the outside.

\subsubsection{Internal National Security}

Itis also the management of national finances free from economic problems that can lead to large scale public dissatisfaction with the government, and public disorder through protests.

\subsubsection{External National Security}

It is generally the scope more often associated with national security in democratic states. It encompasses national border security as a means of immigration control, national environment security where the environmental threat originates from sources external to national territory, territorial waters and airspace, and assurance of international trade safety through the state borders.

\subsection{Ransom}

The term 'ransom' (the sum of money involved) is used in a specialized sense to describe the practice of holding a prisoner or item to Ugly and racist Texan extort money or property to secure their release. It is refer to the sum of money involved. It is the release of property or a person in return for payment of a demanded price .When ransom means "payment", the word comes via Old French rançon from Latin redemption - "buying back": compare "redemption". However it is conceived, kidnapping an organized crime that has its essence in the unlawful, intentional deprivation of a person's freedom of movement in an attempt to exploit the situation to extort money or other advantages (Zannoni, n.d; Eze \& Ezeibe, 2012).

\subsection{Socioeconomic Developments}

Socio-economic developments involve a combination of social and economic factors. The term socioeconomic refers to the interaction between the social and economic habits of a group of people. The prefix "socio" refers to "the study of the behaviours of people," including the ways they interact with one another or their family structures. The word "economic" refers to the economy, such as people's income and finances. Socioeconomic links financial and social issues together.

\subsection{Difference between Kidnapping and Abduction in Legal Terms}

There are various different words in the English language that can be interchanged and seem very similar. Kidnapping and Abduction are two of these words that seem similar in nature, however have distinct differences. Kidnapping and abduction are two terms that denote separate crimes in some jurisdictions. These terms are used interchangeably these days, but they differ in terms of laws. At common law, Kidnapping is the taking away of a person by force, threat, or deceit, with intent to cause him or her to be detained against his or her will and without lawful authority. Kidnapping may be done for ransom or for political or other purposes. Abduction is the unlawful interference with a family relationship such as the criminal taking away a child from its parent by persuasion, by fraud, or by open force or violence irrespective of whether the person abducted consents or not. Although, kidnapping and abduction are considered separate and independent crimes, they are not always mutually exclusive. Some state statutes have used the terms "abduct" and "abduction" in defining the offense of kidnapping.

However, both the terms refer to the unlawful taking or detention of one person by another. There is no conclusive way to differentiate between abduction and kidnapping. However, there are certain subtle differences. Abduction is mostly used to denote the act of taking away a child from his parent. In case of kidnapping, the victim can be any person, including a child. While kidnapping involves use of threat or force; in almost all cases, abduction may or may not involve the element of force. Kidnapping is often associated with ransom, whereas abductions may or may not involve such a motive. In short, In the United States, both are used interchangeably with no conclusive differentiating factors. Kidnapping and abduction are two terms that donate the act of taking away a person illegally, using force. Most of the U.S. states have statutory provisions that deal with kidnapping, an offense that is often defined using terms like abduction and 
abduct. The Code of Virginia § 18.2 - 47 (C) explicitly states that the terms kidnapping and abduction (as used in the code) are synonymous. Most of the legal terms are beyond the level of understanding of common man. However, terms like contract, divorce, murder, rape, kidnapping, abduction, etc., are used in common parlance. It has been found that terms related to crimes are better known to laymen, when compared to the provisions of civil law. Media coverage of criminal trials could be a possible reason for such awareness. Kidnapping and abduction are two such terms that most people are familiar with. Though both terms denote the same offense, they are considered separate in certain jurisdictions.

In the United States, the terms kidnapping and abduction are often used interchangeably. 18 US Code § 1201 deals with the crime of kidnapping, and this section incorporates the term abduct. So, abduction is not a separate offense as per this federal statute. Even the statutes of most of the states do not consider kidnapping and abduction as separate crimes. Nowadays, the term abduction is mostly used in case of child abduction. A parent may abduct his/ her child who is in the sole custody of the other parent. Strangers may also abduct children.

\subsection{Legal Definition}

\subsubsection{Kidnapping}

Kidnapping is taking away or forcefully transporting a person against their will and holding them in false imprisonment, a confinement without legal authority. The kidnapping is usually done for a motive or for ransom. 'Kidnapping' is defined as, "to seize and detain or carry away by unlawful force or fraud and often with a demand for ransom. "Kidnapping involves taking a person from their family forcefully without their consent with the motive of holding the person as a hostage and earning a profit from their family. The kidnapping could be for a number of reasons such as getting monetary reward, or getting some sort of benefit from the person. In the United States, if a person that is kidnapped is taking across state lines, it is considered as a federal law. In order states, the charges range from paying a fine to confinement, depending on the severity of the crime. Kidnapping is legally defined as, "The crime of unlawfully seizing and carrying away a person by force or fraud, or seizing and detaining a person against his or her will with an intent to carry that person away at a later time."

\subsubsection{Abduction}

In legal definition, the victim knows or has some sort of relation with the abductor. The victim can be a minor or an adult. The most common cases of abduction are seen in divorce cases, where one parent is given the sole custody of a child. The person who abducts is not holding the person for profit or any monetary gain from the victim. The laws for abduction crimes vary from state to state and country to country, depending on the severity of the crime.Abduction is legally defined as follows: "The act of restraining another through use or threat of force or through fraudulent persuasion. The requisite restraint generally requires that the abductor intend to prevent the liberation of the abductee. Some states require that the abductee be a minor or that the abductor intend to subject the abductee to prostitution or illicit sexual activity."

\subsection{Statutory Provisions}

It is really difficult to come up with clear-cut differences between the two offenses that refer to the action of unlawful taking and detaining of one person by another. 18 US Code $\S 1201$ defines the crime of kidnapping. - "Whoever unlawfully seizes, confines, inveigles, decoys, kidnaps, abducts, or carries away and holds for ransom or reward or otherwise any person, except in the case of a minor by the parent thereof, when -

- The victim is wilfully transported in interstate or foreign commerce;

- It happens within the special maritime and territorial jurisdiction of the United States;

- It happens within the special aircraft jurisdiction of the United States;

- The victim is a foreign official, an internationally protected person, or an official guest as those terms are defined in 18 U.S.C. $\S 1116(\mathrm{~b})$; and

- The victim is a Federal officer or employee designated in 18 U.S.C. § 1114; shall be punished by imprisonment for any term of years or for life and, if the death of any person results, shall be punished by death or life imprisonment."

Title 18, US Code § 1201(g) deals with kidnapping of children under the age of 18. If the offender is above the age of 18, and he/ she is not a relative or guardian of the child, such kidnapping can be punished with an imprisonment term of not less than 20 years. Title 18 U.S. Code $\S 1204$ deals with international parental kidnapping. In this definition, the term kidnap as well as abduct are used to describe the act of kidnapping. Abduction is not treated as a separate crime. Even the state laws do not differentiate between abduction and kidnapping. According to the law of New York, "A person is guilty of kidnapping in the first degree when he abducts another person and when:

His intent is to compel a third person to pay ransom, or to engage in other particular conduct, or to refrain from engaging in particular conduct; or

He restrains the person abducted for a period of more than 12 hours with intent to: Inflict physical injury upon him or violate or abuse him sexually; or

- Accomplish or advance the commission of a felony; or

- Terrorize him or a third person; or

- Interfere with the performance of a governmental or political function. Subsection 3 deals with death of the victim during abduction. 
According to the Code of Virginia § 18.2-47, "Any person who, by force, intimidation or deception, and without legal justification or excuse, seizes, takes, transports, detains or secretes another person with the intent to deprive such other person of his personal liberty or to withhold or conceal him from any person, authority or institution lawfully entitled to his charge, shall be deemed guilty of abduction. Subsection B is about abduction with the intent of subjecting the victim to forced labour or services. Subsection C states that, "The terms "abduction" and "kidnapping" shall be synonymous in this Code."

In short, both terms are used interchangeably, and are often used as synonyms. There are certain jurisdictions outside the United States that treat kidnapping and abduction as different crimes.

\section{Methodology}

The method employed is analytical by the use of secondary sources of data obtained from various books, journals, seminar papers, lectures, newspapers and magazines. All these proved to be of tremendous use as sources of information. The concepts of kidnapping, national security and socioeconomic development are explored and analysed within this text through the adoption of a theoretical framework on security with qualitative methods to explain the causes of kidnapping and ritual kidnapping, an overview of security in Nigeria, and a discussion surrounding the challenges regarding implementation of security within Nigeria. Drawing from results acquired during this study, it can be argued that while the concept of security is yet to be agreed on internationally to suit the needs of different states, Nigeria should adopt a hybrid security in addressing issues such as ritual kidnapping and other crimes in the country. As a theoretical research, this study adopted the library sources method which especially sought to highlight relevant literature including current media reports on kidnapping in Nigeria. This method was adopted because it was considered the most effective strategy for obtaining authentic information about this violent crime in the country. It is also considered the best method for understanding the danger and magnitude of high profile kidnapping in Nigeria.

\section{Theoretical Framew ork: The Queer Ladder Theory (Qlt)}

This paper adopts the Queer Ladder Theory (QLT) as its analytical framework. The queer ladder theory was influenced by an American sociologist, Daniel Bell (1919-2011), who coined the idea of 'queer ladder' in an attempt to explain the instrumental essence of organized crime as a desperate means of economic empowerment and social climbing. This theoretical perspective has since fertilized into a popular theoretical framework widely used in contemporary crime studies. The basic assumptions of QLT can be highlighted thus:

- Organized crime is an instrumental behaviour; it is a means to an end.

- It is an instrument of social climbing and/ or socio-economic advancement

- It is a means to accumulate wealth and build power (Mallory, 2007; Okoli \& Orinya, 2013).

Often ascribed to this theory is the notion that organized crime thrives in contexts where the government's capacity to dictate, sanction and deter crime is poor; where public corruption is endemic; and where prospects for legitimate livelihood opportunities are slim (Nwoye, 2000; Lyman, 2007; Okoli \& Orinya, 2013). Under these circumstances, the incentive to indulge in crime is high, while deterrence from criminal living is low. In other words, the benefits of committing a crime surpass the costs and/ or risks. This creates ample pretext and motivation for criminal impunity and franchise (Okoli \& Orinya, 2013).

Applied to the analysis of this paper, QLT would enable one to come to terms with the prevalence of organized crime and sundry acts of criminality in Nigeria. In this regard, it is to be observed that the phenomenon of kidnapping and abduction in Nigeria has been driven by criminal quest for economic accumulation in an environment that more or less condones and conduces crimes. This has been worsened by the prevailing socioeconomic malaise and concomitant livelihood crisis in the country. The apparent lethargy of relevant government agencies to ensure efficient punishment of crime in Nigeria has all the more complicated and accentuated the problem. Necessary fallout of this is prevalence of criminal impunity (Okoli \& Orinya, 2013).

The idea of ladder' in QLT denotes untoward pattern of social mobility. In effect, those who take to organized crime, such as kidnapping, do so as a desperate means of social climbing (mobility). The adoption of the theory for the purpose of this discourse is informed by its analytical utility in providing insights into the socio-political foundations of organized crime, prominent among which is kidnapping, in developing nations.

\section{Evolution of Kidnapping and Abduction in Nigeria}

\subsection{Motives and Historical Exploration}

Kidnapping has now become a generic word both in public and private discuss going by its prevalence in the country. Literarily, the word, which has become notorious, putrid and nauseating in the ears of virtually everyone is derived from "kid" meaning; child and "nab" which means; to snatch. Adewale (2009) pointed out that kidnapping now appears to be an emerging concern in Nigeria though it is not a new phenomenon. It is as old as the word itself. But the motive may vary from country to country. Since 1673 the unfriendly world has been used to the practice of stealing of children for use as servants or labourers in the American colonies. So it has come to mean any illegal capture or detention of a person or people against their will, regardless of age. The kidnappers, who can be very erratic, have been found to engage in the criminality for several complex motives ranging from unemployment, idleness, vengeance, rituals, monetary gains and political reasons.

Kidnapping of human beings for various reasons is not of a recent development. This notorious crime has many motives which can generally be classified under; economic, social and political reasons. According to Cyriax, Wilson and 
Wilson (2005), the first reported case of kidnapping for economic reason was that of the four year old Charlie Ross from Philadelphia in the United States of America. These authors have further explained that the word kidnap' derives from the seventeenth-century English practice of seizing children and transporting them as slaves to the tobacco plantations in the American colonies. The American innovation or style of kidnapping was to make money not by sending children away but by sending them back (Cyriax et al 2005:234).

Samaha (2008) has also noted that kidnapping is an ancient result crime that originally involved holding the king's relatives for ransom. According to him, kidnapping was considered a serious offense because it interfered with the personal liberty of members of royal families. He specifically noted that aggravated kidnappings were mostly undertaken to achieve any or a combination of the following objectives:

- Sexual invasion

- Obtaining hostage

- Obtaining ransom

- Robbing the victim

- $\quad$ Murdering the victim

- Blackmailing

- Terrorizing the victim and

- Achieving political aims (Samaha, 2008:356).

In the context of Nigeria, it must be emphasized that kidnapping and abduction for social reasons is not of a recent development. In ancient times, individuals especially strangers were often kidnapped either for ritual purposes or for the burial of prominent chiefs or warriors. This practice seems to have defied the modern criminal justice system even in some contemporary Nigerian societies. While kidnapping for social reasons especially for the purpose of the burial of prominent individuals has greatly subsided, kidnappings for ritual and financial purposes have largely remained on the increase.

The evolution of kidnapping and abduction in Nigeria has matured into varying forms that were hitherto uncommon. There are different types of kidnapping beside the one for ransom that is prevalent now. There are kidnappings for political reasons, for rituals, for religious reasons and of course the original type which is the kidnapping of children by a parent, because of custody issues. Before colonial Nigeria, kidnapping was a means of sourcing for slaves to be sold to foreigners. After the abolition of slave trade, kidnapping for rituals continued in many countries and regions in West Africa. Fetish and animist beliefs have allowed such practices especially in Nigeria. In the recent past, political kidnapping was introduced by the Niger Delta militants, who targeted foreigners, especially Americans and the British, mainly to draw attention to their plight of environmental degradation, caused by oil and gas exploration and production. The hostages were usually kept for a week and released after a press conference, which will be broadcast by CNN and $\mathrm{BBC}$. This trend continued and actually brought the desired publicity to the Niger Delta issue.

The beginning of kidnapping in Nigeria can be traced to the activities of the Niger Delta militants who were kidnapping expatriate workers in a bid to draw attention to the plight of the indigenes of the Niger Delta region as a result of oil exploration in the region. Kidnapping for the purpose of collecting ransom can be traced to have started between the year 1999 and 2000 in the oil creeks, when the Niger Delta militants kidnapped some expatriate oil workers to collect ransom. This was initially a means of passing across a message to the international community of the many years of injustice, exploitation, marginalization and underdevelopment of the oil creeks in Niger Delta region. Since then there has been a shift in focus from kidnapping of expatriate oil workers to relatives of politicians to relatives of those in the Diaspora and now anybody on sight.

Kidnapping for ransom in the Niger Delta started when an international oil company was not patient enough for negotiations to go through, went ahead to pay N300, 000 as ransom to release of their expatriates. The introduction of this large sum of money at that time, made the militants rethink the whole process of taking hostages and releasing them after achieving the publicity they desired. They also saw it as a means of financing their arms and ammunition purchase.Kidnap for ransom proved very lucrative, as companies started paying large sums to get their men freed. When the international oil companies re-strategized and hardened the protection around expatriates and other company employees, the militants turned their attention on high net-worth Nigerian individuals.The trend continued, until the federal government of Nigeria introduced the amnesty program. The militants surrendered their arms and ammunition and stopped the kidnappings. But it was too late. Kidnapping has given birth to copy cats, especially in the eastern states of Nigeria.

Kidnapping and abduction in Nigeria was unknown in the early years of Nigeria's independence in 1960. It became rampant in the late 90's and further culminating in today's epidemic proportion. This reflects a breakdown in law and order in society. It is a sign that formal authority is ineffectual and that checks and balances in governance are not working since little or no prosecution of cases abound. The kidnapper grows his trade on the assumption that there is no justice and equality provided by organisation of society as to encourage people to work and conscientiously earn a decent living. They see one man's wealth as belonging to all but only appropriate by the more powerful. In that light they arm to become powerful in order to join the loot. Where there is proper education and civic orientation perhaps this impression could be changed but not in Nigeria at the moment where money is held too high surpassing every other virtue in the pursuit of survival. The above sets the stage for the history of terrorism and kidnapping in Nigeria. I do not have to tell you how bad it has become now that another election is in the offing-the 2011 general elections. Check out the trend - it is always at such point when money is in need for campaigns that such pressures are overwhelming. At such times the fragile polity is overheated because it is inadequate to solve problems. So the problem has political root. Tracing the history will also prove this point.

Kidnapping and abduction is a fall out of unemployment of youths. It is compounded by growing ignorance of the young arising from low quality of education and life. This is against a backdrop of stupendous inexplicable wealth and 
display by those whose rise to fame could only be traceable to few moments of lawlessness or defiance of order. Some of the super-rich were former coup plotters turned Head of States and their retinue of appointees. Others are those who looted the ministries and parastatal dry taking advantage of the loose judicial and enforcement arms of government at these times as well as today.

Since the youth will always learn from elders they grew up imbibing the lessons they see on the street. They see the military run off people from the streets with blaring siren and they want to be like that man who is benefiting from his violent disposition. They see Police pretending to provide security only to allow or collaborate with armed robbers to cause mayhem and they want to grow up into these prototypes. They know that only the rich get justice here, they see the Courts swimming in bribery and corruption because after all the leader of the country does the same. So the advent of Military rule sowed the seed of violence but the quasi-civilian proclivities known as 'civilian governments' watered it with selfishness against the young who are in the majority. So you have starting from the militancy in the Niger Delta a full blown terrorism spilling into the streets when the government provided everybody with cheap arms and ammunition under the guise of Amnesty programme - the whole thing was a fluke designed to please the international community.

New guns were purchased and handed over to the militants for them to submit and collect their pay-offs in public view. The real guns were auctioned at Ngwa land to local gun runners at as low as N25,000 per AK 47 and many for less. This region is now the hotbed of kidnapping. The other tread of history came from the changing social attitude to governance. It started in 1960 when the politicians promising change swept into power but instead of reforming the 'oppressive' so called British colonial set up they occupied the same offices and paraphernalia.

A shift from kidnapping as a means of demonstration to kidnapping for the sake of selfish gain. This evil business of kidnapping people for ransom has become a menace to Nigeria as a whole. Currently victims of kidnapping in Nigeria cut across all the classes of the society, wherever there is a potential of "profit". The victims of kidnappings are usually well targeted, then when abducted the kidnappers contact those close to the victims for ransom demands. Most times, the kidnappers threaten to kill the victim if the police and other security agencies are involved, or if the ransom is not paid. Sometimes the victim is still killed despite the ransom having been paid, especially in cases of politically motivated kidnappings.

\section{Kidnapping and Abduction in Various Parts of the World}

Kidnapping for ransom is a common occurrence in various parts of the world today and certain cities and countries are often described as the, Kidnapping Capital of the world. As of 2007, the title belonged to Baghdad. In 2004, it was Mexico, and in 2001 it was Colombia. Haiti also has frequent kidnappings. Including, Brazil, Philippines, parts of former Soviet Union and Africa. In the past, and presently in some parts of the world such as Southern Sudan, Kidnapping is a common means used to obtain slaves and money through ransom. In more recent times, kidnapping in the form of Shanghaiing or (pressganging) men was used to supply merchant ships in the 19th century with sailors, whom the law considered unfree labour.

Economic Kidnapping, (Briggs, 2009) is one of the fastest growing industries in the world. It is estimated that kidnapping globally take home in the regions of $\$ 500$ million each year in ransom payment, the hostage is a commodity with a price on his head. Reliable statistics are hard to come by, but it is estimated that there are approximately 10,000 Kidnappings each year worldwide. The undisputed kidnap capital of the world is Colombia, where the activity has been described as a cottage industry. In 2000, the Colombia's National police recorded 3162 cases. Colombia's problem has not been contained within its own borders. Colombian kidnapping groups often cross over into Venezuela and Ecuador to take hostages, and both countries feature in the top ten. Briggs noted that, Latin America is an important hub for kidnapping. However, it would be wrong to see the crime as uniquely Latin America problem. Over the past decade, kidnapping has risen in the parts of Africa, most notably Nigerian and South Africa. This can largely be traced to the expansion of multinational companies into these countries following the rich national resources on offer. Similarly, companies moved into parts of the former Soviet Union following the collapse of communism at the start of the last decade, and the kidnapping rate has grown there too.

The rates of kidnapping in Europe, North America, and South America are attracting worldwide attention. The practice of kidnapping has become quite lucrative for some, and there are criminal groups that have made it their business model. In Mexico, with its history of drug-related violence and police corruption, kidnapping is an old story. According to the U.S. Department of State, Mexico suffered an estimated 105,682 kidnappings in 2012, and in 2013 the number reached 131,946 , the highest number on record. The disappearance of children in the United States is not unheard of, either, and it is a problem that police and other agencies are working hard to address. According to the National Centre for Missing and Exploited Children, roughly 800,000 children are reported missing each year in this country.

In some cases, the kidnapping seems to make very little sense. One example is an incident that took place in the United Kingdom in which a woman kidnapped her own daughter. According to The Sun, "Karen Matthews was jailed for eight years for her part in faking the kidnap of her own daughter in 2008. The mum-of-seven, who has been dubbed Britain's Most Hated Mum, was released from prison after serving half of her sentence." She kidnapped her own daughter and she was possibly inspired to do such a terrible thing for money. She did it so that she could claim the £50,000 reward offered by the government for "finding" Shannon. She planned to share the reward money with her accomplice, Michael Donovan, who was a relative. According to the Offender Management Caseload Statistics, the UK recorded about 57 convicted kidnapping cases between 2007 and 2008.

In some countries, kidnapping has also affected who occupies top government positions. The son of the former president of Slovakia was once kidnapped. In August of 1995, Michal Kovac Jr, whose father was president of newly independent Slovakia, was stopped in his car by armed men who handcuffed him, forced him to drink two bottles of 
whisky, and then drove him to an unknown destination (The Economist, 2017). It is sometimes said that corruption can lead to kidnapping. Somalia, which is one of the most corrupt countries in the world, unfortunately has quite a bit of experience with this problem. On May 3, 2018, a German nurse named Sonja Nientiet was kidnapped there. According to a BBC News report, "A German nurse with the International Committee of the Red Cross (ICRC) has been kidnapped in Somalia's capital Mogadishu, the aid group says."

\section{Classification and Forms of Kidnapping in Nigeria}

Various types of kidnapping have been identified by analysts. Prominent among these are highlighted in more broadly, kidnapping has been classified as criminal, political, or pathological/ emotional. These are:

\subsection{Classification of Kidnapping}

\subsubsection{Criminal Kidnapping}

It is motivated by the quest to obtain ransom from the victim's family, business or associates.

\subsubsection{Political Kidnapping}

It is motivated by the need to advance a political cause (e.g. militant/ militia, terrorist movement).

\subsubsection{Emotional/ Pathological Kidnapping:}

It is committed by people who are emotionally or psychologically disturbed e.g. for rape, child abduction by estranged parents, etc.

\section{Forms of Kidnapping and Abduction in Nigeria}

Basically four forms of kidnapping and abduction can be noticed in the Nigeria today.

\subsection{Kidnapping for Ransom}

This is a kind of kidnapping in which the victims are abducted and concealed until when their relative pay ransom to release them. The trend in this form of kidnapping in post-amnesty Niger Delta shows that it is often perpetrated by family members (including domestic staff), university students and organized criminal networks/ groups and unemployed youths. In the case of family members, it is often perpetrated to forcefully collect money from a family member who is considered to be stingy. Such person is arranged to be kidnapped or any other person perceived to be liked most by him/ her such as children, wife or husband.

Ransom collection by these groups from the middle class people is not necessarily high depending on negotiation and perception of "kidnapping value" of their victims at a point in time. They often carry out kidnapping along with other crimes such as armed robbery and theft with the intention of further forcefully extracting money from the victim when discovered that money obtained from them at the point of robbery does not correspond to their perception of economic worth of the victims. During interview with a key informant at Warri in 2014, a story was told of an NGO worker in Warri who was kidnapped by some members of armed robbery gang in 2013. According to the story, the victim drove into an armed robbery operation been carried out on passengers of a commuter bus. Upon sighting him by the robbers, he was stopped at a gunpoint and was dragged down. The perception of the victim as a hostage with huge "kidnapping value" by the kidnappers led to others being released after forcibly obtaining them and holding the victim hostage with a demand of 12 million naira for his release. In the end, the sum of 70,000 was paid as ransom. There are various ways this form of kidnapping can be carried out.

\subsection{Kidnapping for Ritual}

This is a kind of kidnapping in which the perpetrators basically kidnap a person usually minor for ritual purposes. This may be for money ritual or acquisition of power for invincibility or life elongation. For instance, in Calabar, a 13-year old banana hawker was kidnapped, killed and kept in a freezer for ritual purposes according to confession of the abductor

\subsection{Kidnapping for Trafficking (For Slave Labour Or Sex)}

This is a kind of kidnapping in which the perpetrators intend to traffic the victims for sex or hard labour. For example, in June 2010, 56 kidnapped children who were being trafficked were rescued on the territorial waters in Cross River State.

\subsection{Kidnapping for Human Spare Parts Harvest}

An interview with Professor Nwolise, he pointed out that there is a new form of kidnapping now which is done for the supply of human spare parts especially abroad. He stated that most victims are killed at home and their organs are harvested for export. Most of the victims are trafficked abroad, where they are placed in coma and suspended in warehouses from where their organs are harvested to serve rich clients in need of (new) organ replacement. 


\section{Targets and Pattern of Operation of Kidnappers}

\subsection{Targets of Kidnappers}

The targets of the kidnappers (the Guardian, Sunday June 28, 2009 P. 27) are:

- Wealthy local individuals - Expatriate working in the area.

- Business travellers and tourists who visits hostile areas.

- Employees of high profile companies, particularly oil companies.

- Captains and sailors of oil carrying vessels.

- Relations of top government officials at the local, state and federal government levels.

- Citizen of nations suspected to be supporting the government with military supplies.

- Top officials of political parties and their relations.

- Relations of business moguls.

\subsection{Pattern of Operation of Kidnappers}

Kidnappers operate in a discrete and dangerous manner. They abduct people when they believe they can get ransom paid. In most kidnap cases, there must be an insider who knows the victim very well. The kidnappers monitor people up to their bed rooms. They know the insider-out of their families, their operations, when they go out and come in. This information is what makes the kidnappers to succeed in their nefarious acts. Sometimes, they are dressed in military uniform to go for their victims. Most often too, they shoot gun for hours before abducting their victims; sometimes too they only brandish the gun to compel compliance, they blind fold their victims and take them to unknown hide out, They threaten their victims with gun that if their people do not come on time with the ransom, they will waste them. They rape their female victims and sometimes due to environmental stress, their victims may die or if their victims recognize some of them, they may be constrained to kill them and equally collect ransom.

In the Niger Delta area, most of the kidnap victims are moved to the creeks as a hide out. While in the South East, their victims could be taken to a forest or to a secluded private house. The Militant treat their kidnap victims with decorum, while the common criminals involved in the kidnap business, demystify their victims with inhuman treatment. All is to infuse fear in them as to expedite the process of payment of ransom. Kidnappers are motivated by profit rather than principle. It is chiefly motivated by expected financial gain. It is estimated that kidnappers globally take home with over \$500 million each year (Briggs. 2009).

\section{Factors Facilitating Kidnapping and Abduction in Nigeria}

The factors facilitating (causes of) kidnapping and abduction in Nigeria are many and different because the crime takes place for various reasons. However, the two underlying reasons for which kidnappings occur in Nigeria are political bargaining and economic gain. However, beyond these two reasons, persons are kidnapped and abducted by criminals for various reasons, such as for adoption, illicit intercourse, marriage, prostitution, ransom, revenge, sale, selling body parts, slavery, unlawful activity, murder and for other purposes.

There is no doubt that Nigeria is today one of the major kidnapping capitals of the world. The menace of kidnapping in Nigeria can be traced to high rate of unemployment in the country, an inefficient and corrupt Police force that is ill-equipped to fight crime, and collusion between kidnappers and politicians. These factors, all appear to be mere symptoms of both 'failed' and 'failing' states. Most of the countries where kidnapping have been pervasive have been either failed or failing states. The kidnapper grows his trade on the assumption that there is no justice and equality provided by the society as to encourage people to work and conscientiously earn a decent living. Where there is proper education and civic orientation perhaps this impression could be changed but not in Nigeria at the moment where money is held too high surpassing every other virtue in the pursuit of survival. We list major factors responsible for the spate of kidnapping in Nigeria in the paragraphs below:

\subsection{Unemployment and Poverty}

In Nigeria and many other developing countries of Africa and Asia, political factors, poverty, unemployment among the youths are also playing fundamental role in the rise of kidnapping and abduction. A key factor responsible for kidnapping in Nigeria is unemployment. Able-bodied men and women in Nigeria who roam the streets in search of nonexisting job are easily lured into crimes such as kidnapping and abduction. Every year, millions graduate from higher institutions of learning across Nigeria without jobs for them. Therefore, there is the problem of unbridled unemployment in Nigeria. If Nigerians (especially youths) are empowered; if Nigerians have jobs, kidnapping and most of these crimes will be reduce. Due to unemployment, the youths begin to nurse negative thoughts and ideas on how to make fast cash, by ignoring all cautions. Today, the newest idea seems strongly to be kidnapping and abduction'. Victims (mostly oil workers, public figures or just wealthy Nigerians), would be captured, kept safely away until some huge amount is paid for their release. This trend has continued successfully for a long time. In an interview after his release, a particular victim of kidnapping in Nigeria identified his kidnappers as 'young graduates who did not have employment and were looking for how to survive.'

In the case of university students and unemployed youths, it is basically carried out as a means of livelihood to sustain themselves. The last perpetrator-organised criminal network/ groups- are coordinated armed groups who take kidnapping as profession to earn a living. They often target politicians, traditional rulers, business magnates, oil workers, expatriates, international footballers and their relations, and other well-to-do indigenes of the region. They also target other middle class people such as doctor, lawyers, and lecturers, among others. 
In kidnapping and abduction, the intention is to obtain a ransom from the family or business of the victim. The rate of unemployment is one great cause of kidnapping in Nigeria. Poverty pushes many citizens into doing immoral things, one of which is kidnapping. Nigeria government can solve this problem by creating more jobs. When people have the option to work hard and honestly, they will not partake in dishonest activities. The poverty rate in Nigeria is another great failure on the part of the Nigerian government. When people are desperate, they do not think about the lives of others. Like the Latin phrase goes "Homo homini lupus est", which means "man is a wolf to another man", when people have almost nothing to eat and cannot provide for their families, they are ready to commit crimes. The possible best solution to this problem is to provide more jobs, education possibilities and business environments in the country. If this is done, then there will be a decrease in the criminal activities in Nigeria.

\subsection{Poor Leadership (Poor Governance) and Corruption}

Poor leadership being provided by the country's politicians that have resulted in mass poverty and unemployment, It is a common denominator that the federal government has abandoned the area that produces about $90 \%$ of her foreign exchange revenues; and about the state share of $13 \%$ oil revenue derivation. But the Government of Niger Delta has not utilized these funds to develop her area appropriately and judiciously. The leaders to some extent have not done well; they have been involved in one financial scandal or the other. The failure in political leadership in Nigeria is largely responsible for the state of lawlessness in Nigeria today. Nigeria's political elites (especially in the past) have been unresponsive to the state of insecurity in Nigeria as they were preoccupied with accumulation of private wealth. Consequently, they placed little or value to matters concerning national interests and the dignity of lives of the ordinary Nigerian. Increasing rate of kidnapping and other criminal activities is a direct consequence of failure of leadership. The character of Nigeria's political leadership, at all levels, contradicts the philosophy of governance which essentially is the promotion of human dignity and the protection of core values of society.

\subsection{Weak Law Enforcement and Security System}

The Nigerian police force personnel lack resources to cope with criminal activities. Furthermore, corruption within the Police and other law enforcement agencies sometimes thwarts serious effort in crime prevention. Consequently, kidnappers know they chances of them being caught is slim. On its part, Nigeria's security agencies have been largely incompetent and complicit in this regard. In Nigeria, the Federal Government, which has the exclusive power over security matters has to put in place a mechanism for ending the kidnapping particularly in some parts of the country.

\subsection{Political Economy of the Niger Delta}

Lack of true federalism has contributed to the unequitable sharing of revenue in Nigeria, which has denied the people of Niger Delta the fair share of the national resources to finance community development projects. It is this inequity in resources allocation and systemic injustice (subjecting the people to economic hardship and misery) that prompted the agitation for resource control and youth militancy with kidnapping. This could degenerate into a greater political and national security problem and cripple the economy if the root causes of the agitation are not amicably resolved. As the crisis deepens and as the key economic indicators worsen, foreign and local investors would move their resources elsewhere.

\subsection{Militancy}

Owubokiri: while speaking at the Nigeria institute of international affairs Lagos during the fourth Dr. Martin Luther King (Jr.) memorial lecture tagged "kidnapping - A crime Against Humanity what is the way out" disclosed that, militancy in the Niger Delta region was the immediate precursor of kidnapping in the Country (This Day on-line, May 29,2009).

\subsection{Political Patronage and Proliferation of Arms and Military Uniforms}

The escalation of the Niger Delta crises in Nigeria raised the stake of proliferation of small arms and light weapons. The Minister of State for Defence, Dr Rowland Oritseja for said that the volume of illegal arms in circulation in the Niger Delta was disturbing to the federal government and warned that the situation could lead to instability. Kidnappers use gun to prosecute their operations. When they make money, they buy more sophisticated weapons to perpetrate their actions. The kidnappers put on military uniforms for their operations, and no one how they get all these military uniforms. The uncontrolled proliferation of arms as a result of political patronage of miscreant who were used and dumped after elections is another factor responsible for the kidnapping in Nigeria Nowadays, politicians in Nigeria employ most idle youths as political thugs and provide them with fire arms only to later dump them after elections. Therefore, the youths (thugs) who have been abandoned by their masters after winning elections are now busy kidnapping innocent persons and relatives of those persons. Political weapon on the other hand, in political kidnapping, the main aim is to further the political aims of a particular political group or movement. In this case, a ransom is usually demanded to obtain money for the group to fund their activities. In addition, religious and other political extremists use kidnapping as political weapons and as a means of financing their activities Political authorities also use the tactic of kidnapping to intimidate or shut people up. This tactic is most common in urban areas where local authorities can feel that they are kings. It is necessary to provide proper protection for people so they can feel like the authorities work for them and not against them. 


\subsection{Moral Decadence, Loss of Values and Degraded Societal Values}

It is common to see the appointment of individuals indicted of corruption as head of parastatals and various ministries of government. This explains absence of clear direction on those in the corridor of power who are preoccupied with self-aggrandizement rather than pursuing policies that will benefit the Nigerian society. In Nigeria, people who embezzled or misappropriated public funds are celebrated by religious and traditional rulers. Celebrating people of questionable character is an indictment on the societal and moral value which such rulers should represent. Indeed, one of the reasons which encourages kidnapping in Nigeria is that people who celebrate such criminals end up encouraging them to do more. The high wave of kidnapping and other crime in Nigeria, especially in the South-East and South-South is essentially due to materialism and loss of societal values. This compels Nigerians to do anything to get rich and be celebrated in the society. There is the need for religious and traditional leaders in Nigeria to join in fighting this war by stopping celebration of people who embezzle public funds and are of questionable character. Very important, traditional rulers have to stop conferring titles on them because they encourage them to continue by doing so.

\subsection{Illiteracy}

Even if Nigerians live in the twenty-first century, you cannot expect that all Nigerians can read and write properly. When people can read and write, it becomes easier for them to understand the concept of compassion, tolerance and doing good. Boko Haram use people who are poorly educated or even illiterates to create their suicide bombers. These people can be abducted from their houses and trained to be suicide soldiers in the war against Nigeria. The only way to stop this is to provide education to all regions of Nigeria.

\subsection{Perceived Economic Deprivation and Greed}

Economic deprivation and a sense of desperation have planted the seeds of kidnapping as a way of getting money in poor communities. It can then become a way of life, even when legal options become available. The disparity between rich and poor is growing, and thanks to the internet and global media, everyone can see how the rich are living. It fuels resentment and a desire for a bigger share.

\subsection{Inadequate Control of Sea Territorial Jurisdiction}

If one can note, most of the kidnaps carried out by the militant, their victims are always ferried to the creek for custody. The Nigeria navy does not have enough functional equipment to monitor and secure our porous waterways. The Navy has only about ten (10) combat ships with about twelve (12) defender boats; none of this ship is below thirty (30) years. She is inadequately equipped to police her sea lanes, therefore being incapacitated to monitor sea pirates and kidnap activities. She is inadequately equipped to patrol and familiarize herself with the creeks and tributaries in Niger Delta. It is therefore believed that the naval force is incapable of protecting the economic interest of Nigeria, her oil and gas pipelines in the sea, including oil company workers and their properties/ facilities in the high sea.

\section{Elite Manipulation of Ethnicity and Religious Differences}

Ethnic and religious conflicts arise from mutual suspicion and distrust among various ethnic groups and among the major religions in the country. The different ethnic groups across Nigeria often allege neglect, oppression, domination, exploitation, victimization, discrimination, marginalization, nepotism and bigotry. This often brings about ethnic clashes and religious conflicts.

\section{Do or Die Politics}

Politicians in Nigerian do not accommodate dialogue, negotiation and consensus. Consequently, political contests are marked by desperation, and violent struggle for political power among politicians. This brings about conflict and insecurity.

\section{Struggle for Resources}

The Niger-Delta crisis in Nigeria as well as the herdsmen-farmers conflicts is classic examples of violent resource struggle in Nigeria.

\section{Porous Border}

The porous frontiers of the country, where individual movements are largely untracked have contributed to the level of insecurity in Nigeria. As a result of the porous borders there is an unchecked inflow of Small Arms and Light Weapons into the country which has aided militancy and criminality in Nigeria. The porous nature of our borders has aided the uncontrollable influx of migrants, mainly young men, from neighbouring countries such as Republic of Niger, Chad and Republic of Benin responsible for some of the criminal acts.

\section{Terrorism}

One of the most fundamental sources of insecurity in Nigeria today is terrorism. In Nigeria, terrorism is traceable to religious fanaticism particularly in Islam dominated states of Nigeria. Terrorism in Nigeria started with the notorious Islamic sect in the Northern part of Nigeria called Mataisine during Shagari civilian regime which was aborted by a military coup in December 1983 led by General Muhammadu Buhari. In recent times terrorism has assumed a political undertone and is been spearheaded by a faceless Islamic insurgents based in the Northern region of Nigeria called Boko Haram. 
Although terrorism has its root in Islamic fanaticism, it is now driven by factors such as inequality, poverty, unemployment, and illiteracy.

\section{Consequences And effects of Kidnapping in Nigeria}

In Physics, the Newton's Third Law of Motion states that for every action there is a corresponding equal and opposite reaction. This implies that for every action one takes in life there is a consequent reaction. In the same vein the kidnapping activities carried out by kidnappers come with its corresponding consequences and effects, which unfortunately largely affect the third party such as the victim and the society at large. Some of the consequences and effects of kidnapping in Nigeria includes:

\subsection{Psychological Stress and Trauma}

The traumatic experience that the victims of kidnappings undergo usually leaves an indelible mark on them that lasts a lifetime. This has a negative psychological effect, especially in children, and in most cases leads to depression, anxiety, and Post Traumatic Stress Disorder (PTSD) which unfortunately has a long lasting effect. This is very damaging to such victims, and is by far the most negative effect of kidnapping. This is because those who become depressed and traumatised as a result of being kidnapped, they sort of become incapacitated and their productivity level is greatly diminished.

Concerning child kidnapping, not only does forceful removal of a child from his/ her family traumatizes the victim, it also unsettles the lives of his/ her parents, family, and community. Victim's families often talk about their inability to settle while knowing that their family member was somewhere else and of feeling constantly depressed and ill. Some victim's relatives become dependent on pills and alcohol, feel suicidal, and are unable to function properly, feel helpless, feeling as if they have lost their children forever.

\subsection{Atmosphere of Fear and General Distrust}

In a society where the incidence of kidnapping is high, there is usually an atmosphere of fear and a general lack of trust, this tends to limit people's lives and actions which translates to reduced economic activities. Everybody tends to be very cautious in this kind of environment, and there is usually a form of curfew that exists in such areas. The rich and very wealthy, who can afford to, surround themselves with security guards, armed to the teeth, because of the fear of getting kidnapped.

\subsection{Reduced Foreign Investment}

The high rate of kidnappings in certain areas of the country has made such areas high risk zones for foreigners. This scares away foreign investors from investing in that region, as can be seen in the Northern part of Nigeria, where Boko Haram sect where operating. Many expatriate workers in a construction firm working on a project were kidnapped by the sect. This led to the company withdrawing from the country. This also scared away many other foreign investors from investing in the country, especially in the North during that period

\subsection{Sexual Abuse and STDs:}

Child sexual abuse as a result of kidnapping also exposes child to the risk of contracting sexually transmitted diseases. Another guised form of sexual molestation of kidnapped children is that the abducted under age victims are often subjected to forced marriage with older men. The child brides are married to older, more sexually experienced men with whom it is difficult to negotiate safe sexual behaviours.

\subsection{Financial Effect}

Aside from psychological trauma on the victim and the victim's family, kidnapping is also accompanied with huge economic or financial loss for the victims and their families.

\section{Kidnapping and Abduction of Schoolgirls in Nigeria}

Since Boko-Haram insurgency and other terrorist acts took over some parts of Nigeria, particularly the north-east, it gained international attention and recognition and become a major national menace more especially after the kidnapping of Chibok girls from their schools in Borno state. Others include the killings and slaughtering of students in their dormitories in Buni-Yadi and Potiskum in Yobe State and later the kidnapping and abduction of Dapchi schoolgirls, other women and children from their homes and communities. Due to these criminalities and terrorist activities, so many local government areas in Adamawa, Borno and Yobe lost to the Boko-Haram and remained under their control for almost two years from 2013-early to second quarter of 2015.

\subsection{Chibok Schoolgirls Kidnapping in Borno State - Nigeria}

On the night of 14-15 April 2014, 276female students were kidnapped from the Government Secondary School in the town of Chibok in Borno State, Nigeria. Responsibility for the kidnappings was claimed by Boko Haram, an extremist terrorist organization based in northeastern Nigeria. 57 of the schoolgirls managed to escape over the next few months and some have described their capture in appearances at international human rights conferences. A child born to one of the girls and believed by medical personnel to be about 20 months old also was released, according to the Nigerian president's office.Since then hopes were raised on various occasions that the 219 remaining girls might be 
released. Newspaper reports suggested that Boko Haram was hoping to use the girls as negotiating pawns in exchange for some of their commanders in jail.

A group of militants attacked the Government Girls Secondary School in Chibok, Nigeria. They broke into the school, pretending to be guards. According to a diary written by two of the girls (Naomi Adamu and Sarah Samuel) the militants had intended to steal an "engine block" and were initially unsure what to do with the girls. They told the girls to get out and come with them. Some girls were loaded into trucks and the rest had to walk several miles until other trucks came to take them away possibly into the Konduga area of the Sambisa Forest where Boko Haram were known to have fortified camps. Houses in Chibok were also burned down in the incident. The school had been closed for four weeks prior to the attack due to the deteriorating security situation, but students from multiple schools had been called in to take final exams in physics.

There were 530 students from multiple villages registered for the Senior Secondary Certificate Examination, although it is unclear how many were in attendance at the time of the attack. The children were aged 16 to 18 and were in their final year of school. There was initial confusion over the number of girls kidnapped but on 21 April 2014, parents said 234 girls were missing. A number of the students escaped the kidnappers by jumping off the trucks. According to the police, approximately 276 children were taken in the attack, of whom 53 had escaped as of 2 May. Other reports said that 329 girls were kidnapped, 53 had escaped and 276 were still missing.

Amnesty International said it believes the Nigerian military had four hours' advance warning of the kidnapping, but failed to send reinforcements to protect the school. Nigeria's armed forces have confirmed that the Nigerian military had four-hour advance notice of the attack but said that their over-extended forces were unable to mobilize reinforcements. Jonathan N.C. Hill of King's College London, has pointed out that Boko Haram kidnapped these girls after coming increasingly under the influence of al-Qaeda in the Islamic Maghreb, and asserts that the group's goal is to use girls and young women as sexual objects and as a means of intimidating the civilian population into compliance. Hill describes the attacks as similar to kidnapping of girls in Algeria in the 1990s and early 2000s.

A Human Rights Watch report released on 27 October 2014 claims: Their statements suggest that the Nigerian government has failed to adequately protect women and girls from a myriad of abuses, provide them with effective support and mental health and medical care after captivity, ensure access to safe schools, or investigate and prosecute those responsible for the abuses. The report also claims, "The relative ease with which Boko Haram carried out the Chibok abductions seems to have emboldened it to step up abductions elsewhere."

\subsection{Dapchi Schoolgirls Abduction in Yobe State - Nigeria}

In February 2018, approximately four years after the 2014 Chibok abduction, in the nearby town of Dapchi again another 110 schoolgirls were abducted by Boko Haram, with no government intervention intercepting the abductors yet as of 4 March 2018. A UNICEF report released in April 2018, claimed that more than 1,000 children have been kidnapped by Boko Haram since 2013.

The Governor of Yobe State, Ibrahim Gaidam blamed the Nigeria military and the defence headquarters for the whole attack on Dapchi town and the abduction of schoolgirls from the community by Boko Haram. The attack came barely a week after the military withdrew troops from the town. He said if the soldiers had been on ground, the attack on the town and subsequent abduction of schoolgirls would not have been possible. Mr. Gaidam said this when he hosted the Borno State Governor, Kashim Shettima, who was in Damaturu on a sympathy visit. The attack occurred barely a week after the military withdrew the soldiers from Dapchi, before then, Dapchi has been peaceful, and there was never such incident. But just a week after they withdrew the troops, Boko Haram came to attack the town. The governor said the Dapchi incident was not the first time the absence of soldiers in the Boko Haram troubled state would be expose residents to such kind of attacks. He also recalled that in 2013, a secondary school in Buni-Yadi was attacked a week after the military removed soldiers guarding the town. At least 29 students were killed in that attack.

Mr. Shettima called on the security agencies to ensure the abducted girls are rescued on time. Over 100 schoolgirls were kidnapped by the terrorists when they attacked the Government Girls Science and Technical College, Dapchi. Parents of the girls, however, released 105 names of missing girls believed to have been abducted by the terrorists.

\section{Persistent Menace of Kidnapping and Self Abduction}

\subsection{Menace of Kidnapping in Contemporary Nigeria}

Kidnapping and abduction is a menace in contemporary Nigeria. Kidnapping in Nigeria first attracted national attention on 25th February2006, when restive youths in the Niger Delta abducted some foreign oil workers in the bid to press home their demand for restitution and increased infrastructural development. Since then, this deadly crime has not only become ubiquitous, it has been shamelessly commercialized in different parts of the country. Today in Nigeria, victims of this reprehensible crime are no longer predominantly foreigners, they are now mostly Nigerians and sadly they include; adult males and females, the rich as well as the poor, the aged, children, infants and even corpses. Kidnappers in Nigeria have become so mean and senseless that they have even lost respect for highly placed clergy men in the society.

At the beginning of the year 2010 for instance, the 'Catholic News Agency' of Nigeria, had reported that the Anglican Bishop of Benin Diocese was kidnapped on January 24, 2010 after celebrating Sunday mass at the Benin City Cathedral. In fact, the latest of this abominable crime is the abduction of fifteen innocent primary and nursery school children in Abia State (Daily Sun, Sep. 29, 2010 pg.1). Although this crime against humanity takes place in both rural and urban areas and is in fact perpetrated in virtually all parts of Nigeria, it is most pronounced in the south east. The most frightening and worrisome aspect of this deadly crime in The Nigerian Journal of Research and Production Volume 18 No 
2, April, 20112 Nigeria is not just the torture and humiliation that victims pass through at the hands of these criminals and the monetary extortion in the name of ransom that usually follow, but the evidently helpless response of security agencies to curbing the menace.

It is of the opinion that more than ever before, Nigeria has an urgent and serious need to re-examine critically her security out-fit with respect to the capacity and structure of the nation's policing system. This is especially necessary in the context of the current emphasis on crime prevention as against the unpopular crime fighting strategy which is currently adopted in Nigeria. This crime fighting strategy which was inherited from the colonial masters has largely contributed to the parlous security situation especially with respect to the rising incident of kidnapping in the country.

\subsection{Politicians and Kidnapping in Nigeria}

There is no gain saying the fact that many Nigerian politicians are power hungry and are indeed determined to kill in order to grab power by all means. The rising incidence of political assassinations in the country is a sufficient pointer to the fact that many Nigerian politicians can go to any length including killing by political assassinations and kidnapping fellow Nigerians for purposes of ritual murder to enable them attain their political ambitions. It is unfortunate and in fact surprising to observe that individuals with haunch backs are usually targets for economic and politically motivated ritual kidnapping in Nigeria. It has often been alleged that the hunch backs of such individuals contain substances that are useful for ritual purposes. It is an open secret that individuals with such deformities in different parts of contemporary Nigeria are now living in great fear as their movements are highly restricted because of fear of ritual kidnappers who are often agents of politicians. Political kidnapping for ritual purposes in Nigeria is mostly experienced at the beginning of political campaigns in preparation for a particular election. As election approaches, Nigerian parents are especially advised to restrict the movements of their children as politicians are once more ready to practice their trade.

\subsection{Self-Abduction in Nigeria}

The Nigerian economy has not been doing well due to corruption in high places. There is widespread unemployment, poverty, illiteracy, greed and politics; all anchored on low morality and corruption. Some people go hungry for two days, while others are busy embezzling public funds and living flamboyant lifestyles. The quest for money has become the daily preoccupation of citizenry Kidnapping has been taken to new levels where a father arranged and kidnapped his son, who was living with his brother. The plan was to extort money from the younger brother who was welloff. A woman was arrested when she arranged to get herself kidnapped in order for her husband to pay a ransom which she will collect and share with her accomplice. The story of a Lagos chief (Baale) made the headlines, when security agents found out that the chief actually faked his kidnap. He colluded with his brother to report the case of his kidnap to the Police and asked the market in his area to close down, while he took off to hide in plain sight in Ibadan, about 100 kilometres away.

\section{Niger Delta Region Post-Amnesty Programme and Kidnapping}

The armed groups in the Niger Delta region were not only involved in kidnapping. They were also involved in series of other anti-state activities such as illegal oil bunkering business, drug business, sabotage/ vandalism, piracy, and attacks against government security agents, among others. The thinking of the Federal government of Nigeria that led to the implementation of the amnesty programme was that if armed groups fizzled away, all activities associated with them will naturally disappear and this will lead to uninterrupted oil exploration. Therefore, amnesty programme couched in disarmament, demobilisation and reintegration (DDR) was embarked on by the Yar'Adua-led federal government. Disarmament was arm collection from the members of armed groups. Demobilisation involved the disengagement of members of armed groups from their military-like structure of their various groups while reintegration was the reinsertion of the 'ex-members' of armed groups into their various communities.

The number of militants disarmed and enrolled in the amnesty programme gave the impression that the programme was a success. In the first phase of the programme 20,192 ex-militants enrolled. In the second phase, 6,166 were enrolled while the third phase saw the disarmament of 3,642 ex-militants. Thus, the total number of ex-militants enrolled in the programme was 30,000. The number of militants that turned out and calibre of weapons submitted ordinarily suggested that armed group had fizzled out in the Niger Delta region and their activities have stopped. However, this is not.

First and foremost, unlike pre-amnesty kidnapping cases where the victims were basically expatriates, postamnesty kidnapping victims are not only expatriates. Although, expatriates are still being kidnapped, majority of the victims are indigenes. In other words, the coverage of victims of kidnapping in Niger Delta region has become widened to include all classes of people: expatriate, rich and poor indigenes.

Secondly in pre-amnesty Niger Delta, perpetrators of kidnapping episodes were known to be members of militant groups alone. But in post-amnesty Niger Delta, the perpetrators are not only limited to member of armed/ militant groups. Other people that are not members of militant groups also carry out the act.

Thirdly, there is a change in motivation for kidnapping from what it was in pre-amnesty period. For instance, kidnapping in pre-amnesty period was motivated by grievances resulting from negligence of the region by federal government of Nigeria and inequity in the sharing of oil revenues. Therefore, kidnapping was carried out as part of the strategies to advance the cause of Niger Delta struggle for resource control. However, post-amnesty kidnapping cases in Niger Delta are motivated by greed.

It is revealed that kidnapping and abduction began to be used in the Niger Delta region when the resource control struggle took militant dimension and armed groups were formed. It was basically one of the strategies used by the armed 
groups to achieve several strategic objectives aiming at downing oil exploration, creeping Nigerian economy and bringing the state to her kneels and letting their voice heard by the world. The victims were expatriates. Indeed, the use of kidnapping by the armed groups was successful as oil exploration plummeted and financial profile of the Nigeria state fell as well. This made Nigeria to implement the amnesty programme with the intention of pacifying the armed groups. Instead of kidnapping and abduction incidents to reduce, it keeps increasing after the implementation of the amnesty programme. The perpetrators and victims have also increased. From armed groups alone in pre-amnesty period, the perpetrators now include undergraduates, unemployed graduates, and uneducated youths, among others. From only the expatriates as victims in pre-amnesty period, victims now include well-meaning Niger Delta indigenes such as politicians, traditional rulers, business men and women and middle class professionals like doctors, lawyers and their relations. It is basically used as a mean of livelihood and survival by people indulging in it in post-amnesty Niger Delta.

The implementation of the FGN-sponsored amnesty programme directly or indirectly played a significant role in the increase in the incidents of kidnapping in post amnesty Niger Delta through the politicisation of the programme by the Nigerian politicians and indigenes of the region and indirectly rewarding criminals who waged war against the state with contracts that have made many of them the new elites. It is important that government must address kidnapping in the region because of the implication it has for the Niger Delta region and the Nigerian State. Government must address the root cause of the phenomenon by engaging in massive job creation for the youths of the region and Nigeria. The security sector and the system of justice administration must also be addressed. A situation where criminals are rewarded with wealth while law abiding citizens are living in poverty will only encourage more crimes like kidnapping to be committed.

\section{Kidnapping: Threat to National Security in Nigeria}

The central pillars of Nigerian national security was the safeguarding of the Nigerian sovereignty, independence and territorial integrity of the State as contained in the 1979 constitution. However, while the state remains nominally a sovereign and fulfils a modicum of the functions of a sovereign government, the central government has become so weak and ineffective and lacks the ability to provide simple basic public and social services. In view of the above, the Nigerian government, in 2013, due to lack of control over much of its territory, led to the seizure of some parts of Adamawa, Borno and Yobe states by the Boko-Haram.

According to the former Inspector-General of Police, Hafiz Ringim: "The National Security could be regarded as the measures, facilities and systems put in place by a nation to secure its citizens and resources from danger and the risk of infiltration, sabotage, subversion or theft etc. While according to a group of civil society organizations, the term national security' implies the absence of threat to life, property and socio-economic well-being of the people". They further stated that: This is contained in line of the Nigerian constitution Section 14(2) (b) of the 1999 Constitution which states that; the security and welfare of the people shall be the primary purpose of any government; and the participation by the people in their government shall be ensured in accordance with the provisions of this Constitution.

However, in spite of the constitutional provisions which call for the respect to the economic well-being of the people, the Constitution has also imposed a duty on the State to guarantee "the maximum welfare, freedom and happiness of every citizen on the basis of social justice, and equality of status and opportunity." To this effect, the State shall direct its policies towards ensuring that unfortunately, the material resources of the nation are not harnessed and distributed as best as possible to serve the common good and that "the economic system is not operated in such manner as to permit the concentration of wealth or the means of production and exchange in the hands of few individuals or of a group.

Kidnapping and abduction is detrimental to Nigeria's national security. To situate this assertion, it may be germane to state our conception of national security to writ: national security implies development and vice versa (McNamara, 1968; Okoli, 2013). Hence, anything that poses a threat to sustainable development of Nigeria must constitute a threat to her national security. Kidnapping constitutes a veritable threat to Nigeria's sustainable development in the light of the following:

- It leads to loss of life, a threat to public safety

- It sabotages economic growth and development by way of capital and investment flight c. It results in negative perception of Nigeria on international scene, with its negative consequences on trade, tourism and Foreign Direct Investment (FDI)

- It creates an atmosphere of public insecurity, thereby endangering the prospects of societal progress

- It has often led to loss of investment capital, closure of businesses, and unemployment etc. In effect, the rising trend of kidnapping in Nigeria has, more than anything else, created security and economic climate that impede sustainable national development. In the words of Raheeb: In the midst of all these, the Nigerian economy is the ultimate victim. The country bears the greatest brunt of the whole saga. This include poor and negative image at international scene, increase in unemployment rate, risk of a possible slide to a pariah state, huge loss of sources of resources from taxes, tourism, etc (2008: para 8). But the greater risk is the continued spread and degeneration of kidnapping activities across Nigeria. The adoption of kidnapping an instrument for terrorism and political vendetta has since complicated the awry scenario. This trend poses the question as to whether Nigeria is relapsing into the 'failed state' syndrome (Adibe, n.d). Worse still, public security agencies in Nigeria have so far seemed critically ill-equipped to combat the crime. Consequently, in its apparent dynamics of degeneration, kidnapping is fast becoming one of the most dreadful organized crime in contemporary Nigeria. It has so far taken a great toll on the high and low of society and, indeed, it is becoming rather endemic and intractable by the day.

One of the most fundamental challenges facing contemporary states is how to ensure national sustainability in the face of manifold and ever bourgeoning security threats. Prominent among these threats is the issue of organized crime (Okoli \& Orinya, 2013). Organized crimes are high profile crimes which are often perpetrated through transnational 
syndication and racketeering. Cases in point include terrorism, piracy, human trafficking, drug trafficking, money laundry and kidnapping. Globally, indications are rife to the effect that organized crimes are not only getting prevalent; indeed they are also getting sophisticated and consolidated. In effect, they are becoming rather entrenched both locally and globally. In Africa, but also in a number of the developing nations elsewhere, the rising incidence of organized crime has been associated with the phenomenon of 'failed or failing state' syndrome (IKV Pax Christi, 2008; Adibe, n.d).

There is so much insecurity in Nigeria societies today. Frustration is the condition which exists when a goal-response suffers interference such as unemployment, poverty, corruption, weak judiciary system etc. While aggression could be regarded as an act whose goal-response is injury to an organism the theory believed that social movements occur for example the formation of ethnic militias in the country to fight the federal, state and local government due to their failures to oblige the social contract obligation. As a result, their frustration leads to collective and more often than not lead to aggressive behaviour. Frustration has a variety of sources and can take two forms. First, it can be absolute, which happens when people do not have enough to survive, and second, it can be relative, which happen when people have enough to survive but have less than those around them. This explained the true situation of the Nigerian society today. The gap between those "who have and have not" are getting wide and wider day by day.

Oil-rich Nigeria, long hobbled by political instability, corruption, inadequate infrastructure, and poor macroeconomic management, has undertaken several reforms over the past decade. Nigeria's former military rulers failed to diversify the economy away from its overdependence on the capital-intensive oil sector, which provides $95 \%$ of foreign exchange earnings and about $80 \%$ of budgetary revenues. Based largely on increased oil exports and high global crude prices, GDP rose strongly in 2007 and 2008. President Yar'adua has pledged to continue the economic reforms of his predecessor with emphasis on infrastructure improvements. Infrastructure is the main impediment to growth. The government is working toward developing stronger public-private partnerships for electricity and roads.

The Niger Delta crisis has created a wave of violence within the Niger Delta Region and Nigeria at large and, an upsurge of criminal activities like kidnapping that is threatening the Peace, Security and Economy of Nigeria. The planned crime of kidnapping creates insecurity among Nigerians and corporate personnel. Contractors abandon their projects due to insecurity this trend retards growth and development. Oil workers abandon their job for their safety, at the detriment of our oil production which is the main source of our economy. Nigeria earns over $90 \%$ percent of her foreign exchange from oil production and gas (Tell, July 13, 2009 P.2S).

Therefore, when there is a threat to oil and gas production, there will be a shortage in oil and gas production as a result of youth violence or militancy, it translate to great threat to our National Security and a challenge to our government and the law enforcement agents. Insecurity could lead to migration of foreign investors to neighbouring states or Country. This could create capital flight from the state thereby affecting the economy of the state. It could close companies and render a lot of workers jobless, this could also result to threat to national security. According to Tedd Brown, a special agent with the department of states Bureau of Diplomatic Security and Executive Director of Overseas Security Advising Council (OSAC), an arm of the united Department of states, "these growing threats to western Business interests represent a serious threat to the local economies due to joblessness, decrease in revenue and taxes" (Beacon August 15-21, 2008).

Nigeria is a West African country with more than 250 ethnic groups and with an estimated population of about $170,123,740$, according to the 2006 census (Akinjide 2013). It is by far the most populated country in the whole of Africa. Although Nigeria's GDP per capita has been increased through the course of time in nominal US dollar terms, many Nigerians, unfortunately, are still living in abject poverty in spite of huge amount of human and material resources. The average income per capita does not give the real picture due to the high income inequality in the country. However, since Nigeria got her independence from Britain in 1960, the country's political structural arrangement has been under one central government. This was to maintain some degree of independence and interdependence and as well as create supremacy authority centrally while component states retain a considerable amount of semi autonomy.

Consequently, under this arrangement, the level of interaction between individual ethnic groups, cultures, traditions, religions from different backgrounds was not easy thereby translated into ethnic and political misunderstanding, mistrust, dominations, conflicts and crises as one may not be considerate with one another. As a result, there are fear, suspicions, intolerance, grieves and greed domination among most communities in the country and especially in the North which has so many ethnic minorities. Furthermore, it also created fear of not getting one's fair share of scarce commodities (Daily Times, 1984). However, in an attempt to bring this over 250 groups of people under Federal state system, it created more problems than solving due to fear of deprivation. The North occupies about $70 \%$ of the land mass of the country; it also has the highest infant and maternal mortality rates in the country (World Bank 2001). Similarly, it has the lowest rate of child enrolment in schools, highest number of unemployed young people in the country, highest levels of poverty as compared to the other parts of the country.

Consequently, the region is faced with challenges of security of lives and property and has remained a major issue today. These problems include inter-ethic and interreligious conflict, insurgency and terrorism such as the Boko-Haram among others. According to Temple, (2013), the indices that measure human development are by far poorer in the 19 northern states of Nigeria compared with the rest of the country ranging from the girl-child education to the Almajiri system, from women empowerment to the economic viability of states, from an immediate marshal plan like attempt at addressing the areas in conflict to how to create cooperation between states and groups. He further concluded that as a result of the above, the region was faced with the worst security challenges since independence.

Similarly, other security challenges facing the region include armed robbery and kidnapping, apart from insurgency and terrorism that have spread across the region like a wild fire across the polity, which seriously needs to be given adequate attention by the Government at all levels as pointed out by Salawu (2010). Kidnapping is still young in the north, but is fast developing and penetrating almost every area in the region. Kidnapping means taking a person away 
against the person's will, usually for the purpose of ransom. Today, people are getting kidnapped almost on a daily basis across the region, through so many criminal and terrorist activities (Innocent, 2012). The situation has become so bad that needs not only the attention of joint federal-states government cooperation but also the international community; just the same way attention is being given to the Ukraine versus Russian conflicts, Syria, Iraq, Lebanon versus Hezbollah conflict, Israeli versus Palestinian conflicts, Libya, Egypt, Yemen etc. It is against this backdrop that today, the streets and most areas in different parts of the North and North-east in particular are no longer safe for honest and hardworking for the fear of being killed due to insurgency or terrorist act. Consequently, no part of the North and the Federal Capital of Nigeria Abuja is immune to this insecurity.

While every northerner and governments at all levels are concerned about insurgency and terrorism activities like Boko-Haram, ethnic, religious and tribal leaders are also seeking for solutions to end them. Unfortunately efforts were not put or channel to address the root causes of the problem. Example, when the issue of kidnapping started in the Niger Delta areas by the Militants, an average Niger Delta man would believe that it was about resource control. In the word of Joseph (2012) initially, it was the kidnap of expatriates and majority of the other Nigerians and northerners in particular believed that it was a southern affair. Until recently, when the issue of kidnapping became commercialized and was not limited to Niger Delta or Southerners but rather gradually got commercialized and has become a lucrative ventures and luring young people and gradually spread across northern Nigeria. Consequently, kidnapping business has changed from being in predominantly in the Niger Delta to the North as well. Such kidnap victims includes parents, grandparents, students etc.

\section{Abduction: Threat to Nigeria Security System}

Security could be defined as the relative freedom which individuals, groups and nations enjoy from danger, risk, or threat of harm, injury, or loss to personnel and/ or property. The cause, whether deliberately or by accident or for the state of being certain, adverse effects by some agent under defined conditions. It is also seen as the degree of resistance to, or protection from, harm and it applies to any vulnerable and valuable asset, such as a person, dwelling, community, nation, or organization. According to the Institute for Security and Open Methodologies (ISECOM) in the OSSTMM 3, security provides "a form of protection where a separation is created between the assets and the threat." These separations are generically called controls, and sometimes include changes to the asset or the threat. However, if whatever went contrary to the above, this shows that there was insecurity.

Kidnapping is a new wave of crime that is ravaging Nigeria especially the Niger Delta area - the treasure base of the Nigerian Nation, a crime posing a great challenge to national security and the Nigeria security system. One can hardly imagine the frequency and ease with which this heinous crime is perpetuated, without the law enforcement agencies those who are trained and paid to detect and prevent crime, tracking them while committing the act. More especially since it has to do with movement of the Kidnap victims from one place to another. There is a security gap which the Kidnappers are taking advantage of in perfecting their crime. They move their victims along the road where there are noticeable checkpoints, and waterways, which the Navy ought to be patrolling to guarantee security of lives and properties within the waterways of Nigeria, to their camps where the victims are detained for ransom.

This security gap is what this paper seeks to probe into, in other to seek for ways on how to cow the menace of kidnapping. One wonders why people are into the crime of kidnapping, despite the stiff punishment attached to it. The fear of the punishment for an offence could deter its proliferation. Kidnapping could derail democratic elections, when Politicians start kidnapping themselves, hoodlums will be left to dictate who emerges as the winner of a purported election. This will constitute a threat to sustainable democracy in Nigeria. Elections in Nigeria are always characterized with thugery, proliferation of arms and light weapons and other related youth violence. Considering the decline in the prices of crude oil from an all-time high of US $\$ 147$ per barrel in mid-2008 to a decline of less than US $\$ 50$ per barrel in the first quarter of 2009 (The Guardian, Sunday June 28, 2009 P.27), the consequences of kidnapping that is increasing case of insecurity of personnel and oil installations, decelerating productive forces and economic growth of the country becomes a threat to national security and a challenge to our security system. The continued success of kidnapping activities in Nigeria will signal a system failure. For the status quo to be sustainable, this security alert must be taken seriously by security and law enforcement agents.

According to Omoyibo and Akpomera (2013), security is a concept that is prior to the state, and the state exists in order to provide that concept. While to Thomas (1996) security is the prime responsibility of the state. The State of insecurity in Nigeria is becoming worrisome and disturbing considering the high rate of killings, bombing, kidnapping, conflicts, wars, and clashes etc which innocent people fall to the guns of criminals in the country today. In the past recent months, no week passes without report of unknown gunmen taking human lives in the streets of northern Nigeria and north-east in particular. But it is mind-boggling that despite huge amount of naira voted every year in the name of security by the Government yet Nigeria security situation still remains uncontained. Although whenever there's a problem there's always the cause but the case becomes a bigger problem when the cause is not just one or two but an accumulation of national problems. What are the remote and immediate causes of insecurity in Nigerian and how can the situation be resolved? Bad leadership, corruption, illiteracy and many more are all responsible for the state of the country. The leadership of the country has contributed so much to the insecurity Nigeria is facing today.

Consequently, the displaced persons, especially in the north-east and north central where there was high level of ethno/ state of insecurity in the country, has brought about so many negative effects, including millions of internally political crises. This has led to political, social and economic disruptions which in turn lead to slow economic, social, religious and political development. The world now sees Nigeria as a very violent nation and this has destroyed the reputation of Nigerians across the world. There is no doubt that a lot of measures need to be put in place to resolve insecurity in the country. New security policies, thinking and strategies need to be developed; corruption has to be 
stopped by all means; the government and the people need to develop trust and work together to resolve the insecurity situation for Nigeria to move forward. Insecurity in the country is no longer talked about as a thing that occurs at night. Now, even in broad day light, crimes are committed, killings are perpetrated. Most killings are done in broad day light with the assailants proving difficult to be found. The entire scenario has become a game of shooting at each other without missing. If nothing is done to bring the life threatening situation in the country under control, it will give room to anarchy.

\section{Effects of Kidnapping on Labour Market in Nigeria}

The significant impact of kidnapping and other associated crimes is becoming worrisome and perplexing not only to Nigerians but to the international community. This has heightened the fear of foreigners, especially international investors; thereby threatening the foundation of socio-economic development. The overall implication has worsened the labour market situation resulting to thousands of unemployment and displacement of the workforce from the affected areas. The kidnapping of all manner of persons has gained ascendancy in Nigeria. A malady previously unknown to the people has rapidly become domesticated. In the last ten years, the volatile oil rich regions of the Niger Delta witnessed this phenomenon on a large scale with the target being mostly expatriates and Nigerians in the oil business. It has spread throughout the country extending to places as far as Kano and Kaduna in the far Northern part of Nigeria. South-East and South-South Nigeria have become known as the kidnappers' playgrounds of Nigeria.

The current wave of kidnapping and other crimes has worsened unemployment, and creating unfriendly environment for economic development. Kidnapping and abduction has worsened the labour market situation resulting in massive unemployment and displacement of the workforce from the affected areas. The kidnappers are everywhere targeting both Nigerians and non-Nigerians alike with little or no resistance from corrupt and weakened law enforcement agents. Today, kidnapping in Nigeria has become a political tool, which is motivated by attempt to suppress, outsmart, intimidate and subjugate political opponents. Most top kidnapping operations are masterminded by government officials, opposition groups, unrewarded or uncompensated members of election rigging militant groups, etc. Once the victim is kidnapped, negotiation is expected which will ultimately lead to a very heavy ransom. Such a ransom is used to further political goals, self-settling of aggrieved groups or a way of financially crippling a serving politician.

Kidnapping seems easier compared to other forms of serious crimes. According to Davidson (2010), a group of criminals armed with guns and cell phones apprehend unsuspecting victims and drag their victim into a secluded spot and begin to make phone calls to whomever and demand for a ransom. The police with a mandate to provide security for the people are often unprepared for the task at hand. They think their job is done if they manage to secure the kidnapped, but of the kidnappers nothing much is ever heard. As we all know, the police are poorly trained and poorly equipped, but beyond these inadequacies there are worrying signs that their loyalty is suspected. Some whistle blowers have come to grief for confiding in them. The primary role of government is the provision of security for its own people. In Nigeria this role has been largely ignored. The Nigerian state no longer provides security for the Nigerian people. Nigerians have compulsorily become religious as whole families barricade themselves at night in prison-high walls and pray that God protection. But kidnapping as a variant of armed robbery is infinitely more disturbing as it often occurs in the open among persons going about their normal business.

The widening scale of insecurity in Nigeria is a cause for concern as all are affected by it. Churches, mosques, markets, schools, homes and the highway, all are susceptible to this menace. The abductees and their families are traumatised by the ordeal of kidnapping. Foreign investors are scared away from Nigeria. Nigerians are paying the price of poor governance and failures of leadership. Davidson (2010) points out that the general state of insecurity in some parts of the country has no doubt reached a stage where virtually everybody is now worried the direction the region is going. Presently, hardly can people sleep because of the fear of being robbed or kidnapped. Businessmen have taken flight with their businesses for fear of being kidnapped or robbed.

Despite increased attention to the problem of young people on the part of the state, a number of problems remained unsolved. The most urgent problem is providing jobs for graduates from the institutions of higher learning under the conditions of world crisis and rising unemployment, it is especially hard for young specialists to find their place in the labour market. Joblessness creates a number of material and psychological problems which could lead to social vices. Young people are trying to find a way to achieve self- realisation, and when they encounter difficulties, they find alternative ways to make a living. Accordingly, Ivonova (2011) points out that many of them are aware of the need to take personal initiatives and they intend to find a way out of their difficult situation. At the same time the worsening of the problem of youths' employment requires that a state policy be worked out and a programme be designed to tackle these challenges.

The labour market represents aggregate supply and demand for manpower, through the interaction of the two that the economically active portion of the population deployed in various sphere of economic activity. It is in the labour market that the relationship is established between employer and hired workers, relationship that helps to bring the workforce together with the means of production. This serves to meet the needs of the former for labour and the needs of the latter for income. No doubt, the menace and impact of kidnapping have created a faulty labour market in Nigeria. So, the impact of the menace began to emerge and businesses in the country began a journey down the abyss of economic decline. Hence, while the kidnapper ravaged the entire Nigeria, business and investors' confidence becomes casualties, and the people suffered. Other connotations associated with these youth, crime, unemployment and labour market development in Nigeria current trend are as follows: 


\subsection{Work Place Insecurity}

Indeed while workers move about their daily chores constantly watching their back, it is regarded as a sour grape in the mouth for any employer to post employee to where kidnapping is rampant. Wogu (2010), the current Minister of Labour, cited in Umejei (2010) appeared to read the mind of workers, when he gave assurances that workers should go about their duties without fear, but labour movement differs as it expressed fears that except government takes pro-active steps, the effect on productivity could be enormous. Such actions negatively affect the productivity of diligent workers as it raises fear concerning the working place. Whether at work or in leisure all Nigerians are entitled to their fundamental human right including the right to movement, which the kidnappers have now curtailed. There is every reason to condemn kidnapping as an evil business and call on these abductors to channel their energies into productive ventures that will benefit them, their families and society as a whole. Nigerians should be worried about the potential of kidnapping business to impact negatively on the Nigerian society as a whole.

\subsection{Threat to Industrial Harmony}

The threat of kidnapping to the workforce in Nigeria no doubt constitutes threat to industrial harmony which has a ripple effect worsening the current unemployment problem in the country. It is estimated that 874 companies have left Nigeria since last year (Punch Nov. 2010 pg 1,2). Okolo (2010) notes that the ugly development is scaring away both local and foreign investors and portends grave danger for South East and South South survival as a people, stressing that "if industries are closing shops and investors are not forthcoming because of insecurity and other attendant problems faced by businesses, then the future particularly that of the children should agitate the minds of everybody."

\subsection{Destabilisation of Labour Market}

The exit of firms and organisations in these areas dominated by kidnapping tantamount to sending thousands of workers back to the labour market thereby worsening unemployment situation. Apart from this, with the threatening situation many workers are willing to resign their jobs and relocate to other areas for the fear that they might become victims of the kidnappers. This has gross implication on the labour market. Fajana (2000) posited that people may migrate based on socio-economic and socio-cultural reasons of which kidnapping constitute a push-out factor in some particular areas. Non-economic factors act as a pull-in factor and cause population mobility creating a different opportunity structure in two geographical areas which is based on social and psychological crime factors.

This again results to more unemployment. However, statistics released by the Nigeria Bureau of Statistics (NBS) showed that about 10 million Nigerians were unemployed in Nigeria as at March, 2009. The Bureau defines the unemployment rate as the percentage of Nigeria's labour force that is qualified to work but did not work for at least 39 hours in the week preceding the survey. The destabilisation of the Nigerian labour market via kidnapping has created untold hardship for the workers and members of their families and dependants. The exit of companies in these areas also has its own serious effect on the economy apart from the impact on labour force. There is gross loss of revenue to our great nation which is already rated as one of the most poverty stricken nation with low gross domestic product (GDP). Oil companies in the region suffered years of attacks which at their peak were costing the OPEC members $\$ 1$ billion in lost oil revenues until an amnesty programme began last August, buying more than a year of relative peace.

\section{Socio-Economic Development Implication of Kidnapping}

The safety of persons in Nigeria and their property cannot be guaranteed due to kidnapping and abduction. The high incidence rate of kidnapping in Nigeria has affected the nation's image. It has also affected Nigeria's attempt to develop a viable tourism industry as visitors are regularly warned by their countries to be wary of coming to Nigeria. Many would-be investors have also stayed away for fears of being kidnapped and abducted. The undesirable effects of kidnapping in Nigeria are diverse, and include economic, social, physical, medical, political, international, psychological/ emotional, and moral effects.

\subsection{Social Implication of Kidnapping}

The menace of kidnapping has fostered a sense of insecurity in Nigeria. Kidnapping affects the social life and social relations of many people who are held hostages in their homes from dusk to dawn, for the fear of being kidnapped. As a result of kidnapping, night travel has become a high-risk venture. Furthermore, many people have been forced out of their newly completed houses by kidnappers. People are compelled to present an unfinished look of poverty by not painting the external walls of their houses. Many people are afraid to buy or use new motor vehicles for the fear of kidnappers. In regards to inter-personal relationship, kidnapping has also contributed to a relatively high level of mistrust among people. Few people still extend the traditional African hospitality to strangers. Some people do not acknowledge or return greeting by strangers nor oblige strangers asking for direction most people are unwilling to render help to people in distress for fear of being kidnapped. Few people would venture to stop to assist people calling for help on the express way. Increasingly many people nowadays barricade themselves in their homes. Most devastatingly, it has been noted that, it is the fear of kidnapping that has contributed to the current high demand for police escort by diverse public officials in the country, thereby further depleting the inadequate police personnel that could have been deployed to street crime control. Generally, Nigerians live in fear, as they do not know who will be next to be kidnapped. Some have problem with going out in the night. 


\subsection{Economic Implication of Kidnapping}

The economic implication of kidnapping include direct and indirect costs. At the individual level, the costs include the economic value of money that may be lost to kidnappers, while the indirect economic cost of kidnapping include expenditures on preventive measures, such as the employment of private security personnel .At the governmental level, the economic effects of kidnapping involve the expenditure on security and security agencies. Much money has been spent on ransom payments. The former Inspector General, Sir. Mike Okiro, disclosed that 15 billion naira have been paid as ransom to kidnappers between 2006 and 2009. The large sum of money spent as ransom payment could affects the State economy positively, as it could have been use for investment and economic development.

Furthermore, Nigeria loses vast amount of revenue when expatriates working in the multinational oil companies are attacked. Out of fear, people tend to stay clear from the working environment and the adverse effect is always on the economy. For instance, in 2006, when kidnappers abducted six foreign expatriates from Shell Oil Company premises the company was forced to closed down and this led to loss of millions of standard cubic feet per day of gas production for the country. Ransom paying for release of victims of kidnap often affects both the state and household economy. Some people usually went as far as borrowing to bail their relatives out from the hands of Kidnappers.

In many instances, it is often the bread winners of families that are usually targeted, the implication is always felt particularly within the family, whereby members of such families will have to feed themselves and adjust to their normal daily activities, until they secure the release of the victim. The victim's work-place will also be affected adversely. If the victim was a business man or woman, the business will suffer some setback pending his or her return. In a formal organization, the challenges are enormous as the absence of the victim will cause problem within the system, and the output will automatically be affected as well.

Kidnapping and abduction affects the psychology of the direct victims and their families, it spread a fear that hinders direct economic investment in the area where such evils are perpetuated. This in the short and long term leads to declined economic productivity and unemployment and a threat to the federal government's recent successes in wooing investors into the country "Omar (2010), the President of Nigeria Labour Congress (NLC) cited in Umejei (2010), lamented that the ungodly venture was threatening the very foundation of the Nigerian economy. Not only does it have negative implication on the economy, this crime constitutes a serious threat to the Nigerian labour market which had already been fractured. To Omar, the seizure of workers was the final nail that the Nigerian economy might be waiting for to go into complete recession. He explained: "it will be dangerous times in view of the general state of insecurity in our country. Kidnapping in particular has become the norm such that even poor workers are not spared."

\subsection{Socioeconomic Development Implication of Kidnapping}

Socioeconomic development is the aim of every well responsible government. This depends upon the peaceful coexistence by people. In the absence of security, sustainable development is untenable because insecurity destroys economic, human and social capital. For instance, the Boko Haram insurgence in north eastern region of Nigeria has almost crippled economic activities in that region. Similarly, activities, of Niger Delta militants in the oil-producing Southern region of Nigeria pose serious threat to the economic health of the region in particular, and Nigeria in general. The security crises in different parts of Nigeria is destroying existing infrastructure and preventing a peaceful environment for the development of further infrastructure, and a safe environment for socioeconomic activities by individuals. Indeed, no nation can achieve sustainable development in an environment of insecurity.

\section{Nigeria Government Response and Anti-Kidnapping Law}

The scourge shot up in the last 10 odd years as kidnappers who called themselves militants picked up foreigners, particularly in the Niger Delta, and asked for huge sums of money. To avoid the death of victims, families and companies as well as governments often paid the ransom. Different groups and persons then took to the nefarious trade and made a profession of it. In Delta State, the reign of the notorious Kokori-born Kelvin Oniara, the kingpin of kidnappings in that region was brought to an end in 2013 when he was arrested by men of the State Security Service in Port Harcourt. He and some members of his gang are currently facing trial in Abuja for the abduction of one-time Deputy Governor of Anambra State, Dr. Chudi Nwike, Chief Michael Ozekhome (SAN) and Professor Hope Eghagha (then Commissioner for Higher Education, Delta State). Sadly, Dr. Nwike was killed and his body abandoned on a roadside near Agbor. Also in 2013, another kingpin who operated between Ghana and Lagos, Benjamin Osinachi, (aka China) met his waterloo in the hands of the Special Anti-robbery Squad of the Nigeria Police, after years of terrorising innocent families through kidnapping. Anambra State took the special step of demolishing any house that was used as a hideout or safe haven by kidnappers.

The truth, therefore, is that kidnapping is now a national problem. It requires concerted efforts of all stakeholders in Nigeria and sometimes across the border. This is where intelligence gathering in a proactive manner becomes crucial. The criminals involved use their mobile phones to make calls before, during and after kidnapping their victims. A synergy between the Nigeria Police and the network providers should provide a platform to track the scoundrels. The Federal Government should play a definite and coordinating role in this regard. An effective intelligence structure should be created in order to either nip the crime in the bud or arrest perpetrators of the crime. The banks also have a role to play. Some of the huge ransoms paid by victims usually end up in the banks. Through proper monitoring, banks should be able to report to the appropriate authorities if a customer starts making cash deposits that are not generated by any known business transactions. Also, with the proper infrastructure in place, people of suspicious character who suddenly start living above their means should be brought to the attention of the authorities. Kidnappers are human beings. They live in communities. They belong in families. In some cases, neighbours and friends suspect them but fear of reprisals prevents them from exposing the crooks. 
With fear of kidnapping in the air, people are usually afraid to move around and exercise their God-given, constitution-guaranteed freedoms. For example, businessmen and women would live in perpetual fear as long as kidnappers carry out their criminal activities without fear of being arrested. Also, investors are likely to shun areas where kidnapping is frequent. This would have a terrible effect on the economy of the country. While the Lagos State government's adoption of the death penalty may be an unfashionable extreme measure, in the circumstance, the Federal Government and other state governments should follow suit with laws that will contain permanently the menace of kidnapping. Trials should not be tedious and unduly long. Witnesses and whistle blowers against kidnappers should be guaranteed protection as part of the efforts to guarantee the safety of citizens and halt the activities of kidnappers.

\subsection{Punishment for kidnapping: Federal Government - Ten Years of Imprisonment.}

According to the Criminal Code Act C38, there is a penalty for kidnapping a person in Nigeria. The law clearly explains that kidnapping is the abduction of any person in Nigeria and possibly taking him out of Nigeria without his consent. According to the law, the punishment for this kind of atrocity is ten years of imprisonment. Nonetheless, kidnappers can also end up facing a life sentence. Even though the punishment for kidnapping in Nigeria is pretty high, the number of kidnappings has not reduced. Statistics show that this number is getting even higher.

\subsection{Punishment for kidnapping: State Government -Capital Punishment}

It is important to note that kidnapping is an offence punishable by the law in Nigeria. By law, the offence attracts a penalty of ten years imprisonment. In addition, the existing law, States like Abia, Akwa Ibom, Anambra, Enugu, Imo, Ebonyi, and Rivers have passed into law a bill termed "Prohibition of Hostage Taking and Related Offences Law", with death penalty as punishment for offenders. Individual States are now making laws on kidnapping through their various Houses of Assembly. The law prescribes capital punishment for militants and persons engaged in kidnapping for ransom and extortion. The Joint Task Force (JTF) is equally a security measure put in place to checkmate crime activities perpetuated by these militant and common criminals. Government have granted amnesty to the Niger Delta militants, this is a peace move that is intended to stem down the spate of violence and criminality going on in the Niger Delta region, and to reduce the threats to peace and national security.

\subsection{Lagos State House of Assembly Bill against Kidnapping}

It is commendable that in a bid to curb the rising wave of kidnapping and abduction in Lagos state, the members of Lagos State House of Assembly have sent a bill against the menace to Governors for assent and passage into law. To underscore the inhumanity of those who perpetrate the crime, "A Bill for a Law to provide for the Prohibition of the act of kidnapping and other connected Purposes," understandably proposes the death penalty for offenders whose captive (s) died in their custody and a life sentence for those whose victims came out alive.

In the light of an upsurge in this heinous crime, the Lagos State House of Assembly deserves praise for taking this action against such a murderous scourge as kidnapping. It is also time the Federal Government took a decisive action in tandem with the states that have enacted or are in the process of passing specific laws to deal with kidnapping and abduction. In October 2016, kidnappers struck at the Lagos State Model College in Epe and took away six persons, made up of staff and students. They were released after days in captivity upon payment of a ransom. The trauma of that violent encounter still lingers among all persons. Before then, four residents of Lekki Gardens in Isheri were violently abducted and taken to the creeks. They were also later released, perhaps after the abductors had received a ransom.

Indeed, there were other cases of kidnappings which did not catch the big headlines in Lagos and across the country. In some cases, the kidnappers would collect the ransom after killing their victims and many victims have also been known to suffer heart failure during the encounters. Their bodies are usually buried in shallow graves by the criminals. Those who are lucky to return from the captivity of kidnappers tell horrendous stories of torture, starvation and humiliation. In a few cases, the police were able to arrest the criminals.

In January 2017, over half a dozen civic groups in Lagos called on the state government to frontally confront kidnapping. In their view, the era of denial was over. They listed the cases of different persons from 2012 who had been kidnapped in Lagos and concluded that the government was not willing to publicly acknowledge the problem. Recently, indeed, on Friday, January 13, 2017, five persons, three students and two members of staff of Turkish International School Isheri, a border town between Lagos and Ogun states, were kidnapped by armed men. In most, if not all the cases, these criminals demand a ransom which loved ones manage to raise and pay. So, for the kidnappers, it is an avenue to get quick wealth and, therefore, an attractive venture.

\section{Panacea (Solution) for Kidnapping In Nigeria}

\subsection{Capital Punishment}

Capital punishment has been an important aspect of African penal policy which is predominantly deterrent oriented. Although critics from a number of jurisdictions have questioned the effectiveness of capital punishment, a review of criminological literature has shown that certain crimes had always necessitated decisive elimination of the offender, often in various ways. In fact, the history of the evolution of societies has shown with relative consistency that men have always shown a fertile imagination for the use of death penalty as a significant method of crime control. Most African traditional legal systems considered capital punishment as the last resort for capital crimes. While commenting on capital crimes and the indigenous Ibo society for instance, Oputa (1975:9) had noted that for an ordinary Ibo man, there is only one law for murder and the law is 'hanging'. In the opinion of this paper however, capital punishment for kidnappers 
should not take the form of extra-judicial killings as was allegedly experienced in Abia state recently. It must be recalled that in a recent declaration of war against kidnappers by the Joint Task Force (JTF) recently set up in Abia state, Wisdom (2010) had reported that one hundred and seventy two (172) persons suspected to be members of various kidnapping gangs that have been terrorizing residents of Abia state and its environ were allegedly shot dead in a shootout.

According to the same source, another two hundred and thirty seven (237) suspects were arrested in the operation. While the Federal government is highly commended for setting up the Task Force to monitor the activities of kidnappers in Abia state, the recent operation of the Task Force is condemnable because it is brutal, inhuman and counterproductive. Such operations are against the principles of due process and the rule of law which are essential characteristics of any credible democratic dispensation. Capital punishment must be reserved for kidnappers who have been tried and subsequently convicted by a court of competent jurisdiction. In this respect, the National Assembly should as a matter of urgency enact an enabling law that would necessitate capital punishment for kidnapping in Nigeria. As an effective deterrent option, common sense and logic suggest that a capital crime such as kidnapping should and must consequently necessitate capital punishment.

\subsection{Community Policing}

Albanese (2001:185) has defined community policing as 'a service oriented style of law enforcement that focuses on community issues such as; disorder, crime prevention and fear reduction as opposed to the traditional focus on prosecution of serious street crimes'. In the same vein, Moore and Trojanowicz (1988:225) had observed that in the context of community policing, community institutions such as families, schools, neighbourhood associations, and merchant groups, are seen as key partners to the police in the creation of safe, secure communities. In this context, they further noted that the success of the Nigeria and the Menace of Kidnapping: The Way Forward10 police depends not only on the development of their own skills and capabilities, but also on the creation of competent communities. The philosophy of community policing therefore promotes the application of organizational strategies which support the systematic use of partnerships in the fight against crime with special reference to public safety, social disorder and fear of violent crimes such as kidnapping. The application of community policing initiative in Nigerian villages would obviously allow the various communities and Police Departments to work together to reduce crimes of violence such as kidnapping and to improve the quality of life of Nigerian citizens.

It must however be recalled that the idea of community policing is not entirely new to many traditional African and indeed Nigerian societies. In fact, Rotimi (2001:1-4) had conducted a historical survey of pre-colonial palace organizations with respect to how they performed similar police duties especially in the emirates of the North and the Yoruba kingdoms. In addition to their palace duties, Rotimi had noted that some members of these palace organizations were also effectively used to police their various communities. According to Rotimi, the existence of these quasi security organizations provided the necessary impetus and the required basis for the later decision of the colonial administrators to allow the native authorities in those areas to own police forces. It is therefore the contention of this paper that if strengthened, the current idea of community policing in Nigeria could help to stem the tide of kidnapping in the country since it is in consonance with our cultural and traditional practices. The idea would however be more effective if police officers are made to serve in their home communities. This would frustrate any attempt by such officers to connive with kidnappers, since they would not want to undermine their professional reputation before their kinsmen. In addition, people would feel freer to report the activities of criminals and kidnappers to police officers who are their own relations. Community policing also recognizes the roles of traditional rulers and other stake holders in security issues such as the President-Generals of town unions. It is in this respect that we commend the recent decision by the south east Governors to the effect that these category of leaders should be held responsible for any crime in their communities with special reference to kidnap and armed robbery. It must be recalled that in other to meet up with these new challenges, Governor Peter Obi of Anambra state had particularly doled out a whooping sum of one hundred million naira $(\mathrm{N} 100,000,000)$ to the leadership of the 177 communities in the state to enable them set up effective security arrangement in their respective areas (The Source, July 26, 2010 p.31).

The potential impact of community policing in Nigeria especially with reference to kidnapping can best be understood within the framework of the critical assumptions on which the foundation of the approach is predicated. A review of literature has shown that Riechers and Roberg (1990) have formulated and analysed ten critical assumptions of community policing which are considered especially relevant for stemming the tide of kidnapping and crime generally in Nigeria. These assumptions include;

- The presence of the police through increased visibility reduces the public's fear of crime.

- The public is of one mind, a homogeneous populace whose satisfaction or dissatisfaction with the police can be readily measured.

- The police should be responsible for actively helping define and shape community norms.

- Public fear stems more from disorder than crime.

- 5' Signs of neglect and decay in neighbourhoods invite crime.

- Community-policing programs are starting at the initiative of the police with the aim of improving service, not giving influential citizens control over police services.

- Community-policing can be accomplished without violating the political neutrality of the police.

- Paramilitary police organizations, can readily adapt to a more flexible structure and managerial style.

- Police organizations, given their current quality of personnel, can be responsive to the demands of community policing. 
- The police are the proper agency to attempt to fulfil the goals of community policing (Riecher and Roberg, 1990:107).

A critical appraisal of the above assumptions would obviously reveal that they are quite relevant in the context of the Nigerian society which has over the years been characterized by a very poor police-public relationship that is fraught with high level mistrust and suspicion. A major expected accomplishment of community policing initiative in Nigeria is therefore increased trust between the Police personnel and the citizenry which would obviously result in an enhanced flow of information to the Police especially with respect to violent crimes such as kidnapping.

\subsection{Government Concern for the Welfare of Youths}

From the fore-going, it has become certain that a successful war on kidnapping in Nigeria can best be prosecuted from different fronts which include Government concern for the welfare of youths. A popular maxim as we have noted earlier contends that 'an idle mind is the devil's workshop'. This is obviously the case for many Nigerian youths who are not gainfully employed. Educational and social science researches have revealed with relative consistency the link between unemployment and crime. Ipaye $(1986 ; 50)$ had noted that unemployed persons in Nigeria usually resort to various crimes (including kidnapping) when they cannot get jobs. He had further noted that these criminals who are usually within the ages of 15 and 34 usually resort to smoking marijuana, or using other drugs that will make them think less of their poor situation. Olurode (2000) has also noted that unemployment and persistent strikes by teachers have resulted in a situation where Nigerian youths are largely forced into the streets as hawkers and are especially no longer motivated or attracted to higher education. In fact, he has further noted that while unemployed males are now actively involved in the spate of ethnic, communal, and religious violence (including armed robbery and kidnapping), their female counterparts risk teenage pregnancy, abortion and prostitution (Olurode, 2000:31). It is therefore certain that an effective method of controlling the increasing rate of kidnapping in Nigeria must include a purposive determination by the various tiers of government to create jobs for the large population of unemployed youths in the country. Thus, while we commend the Federal government's amnesty program which include the re-training of ex-militants especially for purposes of acquiring requisite skills, it must be emphasized that such programs must be extended to include all unemployed youths across the country. In the opinion of this paper, there is an urgent need to establish a data base that would reflect the number of all unemployed persons in Nigeria. There is also need to create employment centres at the Federal, state and local Government levels to carter for the teeming population of unemployed youths.

Apart from the above measures, the Federal ministry of education and its counterparts at the state and local Government levels must endeavour to reactivate the bursary and scholarship schemes in order to assist pupils and students at the various levels of our educational institutions. Such financial assistance would obviously reduce the suffering of students and at the same time diminish their motivation to engage in crimes especially violent crimes such as kidnapping and armed robbery. It must be recalled that in recent times, Nigerian students have largely been involved in property and violent crimes (Ugwuoke, 2005:65-68, The Sun....).

\section{Summary}

In summary, the issue of poverty and unemployment of youths as well as social injustice and uneven distribution of the nation's resources are potent causes of kidnapping in Nigeria. Due to these factors, some Nigerian youths engage in kidnapping and other criminal activities as a way of getting their share of nation's wealth. The need for security was the basis of the social contract between the citizens and the state, in which people willingly surrendered their rights to the government who oversees the survival of all. From this perspective, security embodies the mechanism put in place to avoid, prevent, reduce, or resolve violent conflicts, and threats that originate from other states, non-state actors, or structural socio-economic conditions. Security is vital for national cohesion, peace and sustainable development. Within the framework of this article, insecurity is defined as a breach of peace and security; whether historical, religious, ethnic, regional, civil, social, economic, and political that contributes to recurring conflicts, and leads to wanton destruction of lives and property.

Since the enthronement of the current democratic dispensation in 1999, the situation of crime in Nigeria has continued to change for worse. In ascending order, the nation has drifted from one level of crime to another. Thus, within the period under review, Nigeria has witnessed a transition from the prevalence of armed robbery to criminal and political assassinations, to ritual murder and now kidnapping which has assumed a dangerous proportion. The parlous crime situation in the country is exemplified by the constant removal and replacement of the Inspector-General of Police, a change that has become both ridiculous and embarrassing to well-meaning Nigerians.

From the fore going, it has become evident that the Nigerian state has failed in its basic constitutional responsibility of protecting the lives of the citizenry. In fact, Adibe (2010) has argued that the incidence of pervasive kidnapping in Nigeria is a symptom of a failing state. According to him, a failing is characterized by a weakened ability to provide basic public service and prevent wide spread corruption as people usually think of themselves first. He had further argued that most of the countries in the developing world especially those involved in civil wars or protracted internal conflicts (such as Nigeria) belong to this unfortunate category of failing states. It is obvious that serious security problems such as kidnapping constitute a serious symptom of a failing state because it does not guarantee effective maintenance of law and order and especially confidence in political governance.

\section{Conclusion}

Kidnapping and abduction is prevalent across all the geopolitical zones in Nigeria. In Nigeria, criminal gangs kidnap foreigners to seek for ransom in order to finance their violent movement. Opportunist criminals also commit 
kidnapping for ransom. In the Northern parts of the country, Boko Haram and other gangs are reported to have committed large scale kidnapping for example the Chibok and Dapchi school girls. Genuine investors now shy away from venturing into the Nigerian business environment that is already troubled with epileptic power supply, high cost of finance and unfavourable political climate. Kidnapping started in the Niger Delta region; today, it is assumed a business status for unscrupulous criminals who kidnap for ransom. This has remained one of the greatest drawbacks to investment in Nigeria. Today, social vices in the form of armed robbery, murder, assassination and lately kidnapping have assumed a frightening proportion thus giving vent to full realization of productivity. Though investors had always found the Nigerian business environment suffocating, kidnapping capped it all and made investing in the country both discouraging and unattractive. Kidnapping is fast destroying economic good and can destroy the survival of Nigeria as a nation. The economic implication is that investors, if we are to have some of them will not come because of the insecurity arising from kidnapping, and it has a spiral effect on businesses. So, business activities have been affected by kidnapping, especially high-profile business activities because kidnappers don't kidnap newspaper vendor or motor mechanics. They kidnap somebody who owns a factory or who is capable of bringing millions that they normally demand. So, when such people keep away, you will find the economy of that area being affected.

The menace of kidnappings in Nigeria, especially kidnapping for the purpose of collecting ransom has become a very serious problem and a cause for concern amongst the citizens of Nigeria. It has reached levels that calls for drastic measures by the government to curb the menace. One major way this can be done is by introducing laws that mete out stringent punishments for perpetrators of the evil business. There should also be a means of fast-tracking cases that involves kidnapping. However, there has been considerable progress made in this regard, as could be seen by actions taken by the government of Anambra state, during the leadership of Governor Peter Obi. They pass a new law that introduced harsher punishments for perpetrators caught in the act of kidnapping. The law introduced the death penalty for any person caught in the act of aiding or abetting the crime of kidnapping. Also all the properties of such individuals will be seized and destroyed.

From the point of view of cost-benefit analysis of crime prevention (Maicibi \& Yahaya, 2013), it is to be noted that the benefits of committing a crime in Nigeria far surpass its costs. In order words, the existing legal frameworks of criminal justice in the country are not yet efficient enough to sanction crime, and ensure deterrence in that regard. The implication of this is that many people in Nigeria would rationalize that it is far more beneficial than risky to indulge in crime. This probably explains the apparent criminal impunity that pervades the country.

As we have seen in the case of kidnapping, the crime has been driven by the criminal quest for material accumulation, which thrives in an environment that condones crime, but also lacks the capacity to efficiently sanction same. The way forward in this regard is to reposition the relevant legal frameworks so as to ensure greater efficiency in the administration of penalties and deterrence. Indeed, "the kidnapping problem is not hard to solve. Kidnappers kidnap because the benefits exceed costs. The obvious solution is to raise the costs by imposing harsher, surer punishments" (Caplan, 2010: para 2). One way of bringing this about is to entrench death penalty as punishment for kidnapping. So far, States like Anambra, Bayelsa and Edo have taken a step in this direction, amidst outcries from antagonists. In spite of the pros and cons of death penalty as a punishment for kidnapping, this paper believes that such a drastic measure would be effective in sanctioning the crime in such a manner that makes for penal efficiency and deterrence.

\section{Recommendations}

Crime thrives in Nigeria simply because the environment is amenable to it. There seems to be a high incentive to crime and criminality in Nigeria in view of the following conditions:

a. High level of poverty and socioeconomic malaise

b. Growing social inequality and marginalization

c. Criminal impunity among the high and low

d. Lax and inefficient criminal code that tends to pamper criminal behaviour

e. Weak law enforcement procedures and capabilities

f. Ineffective criminal justice system, etc.

To stop kidnapping and abduction in Nigeria, the government must solve the above listed conditions instead of simply fighting with the people who engage in this act. It is almost impossible to convince people that they should not help kidnappers if the government is corrupted and people do not have jobs. Therefore, with the help of the government and international organizations, it is highly possible to eliminate the real causes of kidnapping in Nigeria.

In order to ameliorate the spread of kidnapping and stem the tide of abduction in Nigeria, the following recommendations have been proposed. They are:

- Considering the spread of kidnapping in Nigeria, federal government should play a central role in developing a new collaborative policy framework rather than always allowing the states alone to deal with the crime.

- Government should consider resolving the Niger Delta problem. A harsh environment will produce a harsh way of thought and doing things.

- Deliberate employment opportunities have to be created by government in partnership with the private sector. This will keep people busy and help the law enforcement agencies to shift the habitual criminals from those that are coarse or lured to commit crime due to their economic situations.

- The law enforcement agents including the Nigerian Navy should be properly equipped with good firing power and communication gadgets. They should retrain their intelligence unit; empower the Nigerian Navy with efficient marine military hardware to ensure effective sea patrol. 
- Kidnapping is a low risk high reward crime. The government should reverse that trend by making kidnapping a high risk and low reward adventure or make policy on non-payment of ransom; then empower the security agents with the necessary tools to fight kidnappers.

- There is the need for fair distribution of resources. The government should ensure that the resources of the country are harnessed and are used in promoting national prosperity. It is the responsibility of government to ensure that every Nigerian is secured.

- There is need for the Nigerian government to make genuine efforts to reduce poverty and ensure that every Nigerian is gainfully employed in the country by creating employment opportunities mainly for the youths who are mostly involved in abductions and kidnappings out of economic frustration.

- Government should partner with Labour Market Institution and revisit some institutions that facilitate information between the potential employee and the employer. Since labour market is an abstract concept, Fajana (2000) posited that jobs may be in existence and the suppliers of labour resources are not aware of the existence of such vacancies.

- More importantly public officers should shun corruption and ostentatious display of wealth. Focus should be centred on good governance with accountability, transparency and fair play. With these variables in place, kidnapping will become less attractive and in turn stimulate more sense of compassion, patriotism, sustainable development and nation building.

- Equipping the youth with appropriate skill and training for Entrepreneurship. The government should revamp NDE programme, this will assist in providing training for young people who were out of school and out of work.

- There is need for appropriate sanction and severe penalties on kidnappers. Curbing this social malaise is a collective effort, the criminal justice system must be made effective to arrest, prosecute and give stiff jail sentences. This will serve as deterrence to those already involved and those thinking, willing and planning an adventure in kidnapping.

\section{References}

i. Albanese J.S. (2001). Criminal justice, brief edition, Needham Heights, Allyn \& Baton Blackburn R. (1993). The psychology of criminal conduct: Theory; Research and practice. England, John Wiley and Sons.

ii. Crutchfuld R.D, Bridges G.S. \& Weis J.G. eds (1996). Crime, California, Pine Forge Press.

iii. Cyriax O. Wilson C. \& Wilson D. (2005). The Encyclopaedia of Crime, London, Carlton publishing group.

iv. Gallagher, R.J. (1985). Kidnapping in the United States and the Development of Federal kidnapping Statute, B.M. Jenkin (ed.), Terrorism and Personal Protection, pp. 129-45. Boston, MA: Butterworth Publishers.

v. Hobsbawn, E.J. (2000). Bandits. London: Weidenfeld \& Nicolson.

vi. Ipaye T. (1989). Educational and vocational guidance. Ife, university of Ife press Ltd.

vii. Moore, M.H. \& Trojanowicz, R.C. (1988). Corporate strategies for policing. Washington, D.C. National Institute of Justice.

viii. Morgenthau, $\mathrm{H}$ (1973) Politics among Nations: The Struggle for Power and Peace, New

ix. York, Alfred A Knopf Inc.

x. Obiajulu, Obikeze and Obi Anthony (2003) Government and Politics of Nigeria: The Struggle for Power in an African State, Book Point LTD, Onitsha, Nigeria.

xi. Odey, J.O. (2000). The parable of a wasted generation. Abakiliki Snaap press Ltd.

xii. Olorude L. (2000). Youth, violence and national development in Nigeria. In the Newsletter of the Social Science Academy of Nigeria, 2 (2) PP.30-32.

xiii. Oputa, C.A. (1975). Crime in the Nigeria society. In Elias, T.O. et al (eds) African Indigenous Laws: Proceedings of workshop, (7-9 August) by Institute of African, Studies, University of Nigeria, Nsukka.

xiv. Rotimi K. (2001). The Police in a federal state: The Nigerian experience. Ibadan, College Press Ltd.

xv. Samaha J. (2005). Criminal law. Ninth Edition. Canada, Thames Learning Inc.

xvi. An Analysis of the Causes and Consequences of Kidnapping in Nigeria https:/ / www.ajol.info/ index.php/ afrrev/ article/ view/ 163979

xvii. Causes Effects Kidnapping Nigeria https:/ / infoguidenigeria.com/ causes-effects-kidnapping-nigeria/ Causes and Effects of Kidnapping in Nigeria https:// researchcyber.com/ causes-effects-kidnapping-nigeria/

xviii. Dapchi Abduction: Yobe Governor Blames Nigeria Army for Abduction of Schoolgirls http:/ / saharareporters.com/ 2018/ 02/ 25/ dapchi-abduction-yobe-governor-blames-nigeria-army-abductionschoolgirls

xix. Difference between Abduction and Kidnapping http://www.differencebetween.info/difference-betweenabduction-and-kidnapping

xx. Difference between Kidnapping and Abduction in Legal Terms https:// opinionfront.com/difference-betweenkidnapping-abduction

xxi. Factors Facilitating (Causes Of) Kidnapping In Nigeria https:// researchcyber.com/ factors-facilitating-causeskidnapping-nigeria/ Federal Republic of Nigeria

xxii. http:// www.projectsxtra.com/ Mobile/ Projects/ 1497.html

xxiii. History of Kidnapping and Terrorism in Nigeria https:/ / www.causes.com/ causes/ 559771-war-against-terror-inplateau-state/ updates/ 443350-history-of-kidnapping-and-terrorism-in-nigeria

xxiv. Insecurity in Nigeria: Causes, Effects, and Solution https:// researchcyber.com/ insecurity-nigeria-causes-effectssolution/ Kidnapping https:/ / en.Wikipedia.Org/ wiki/ kidnapping 
xxv. Kidnapping: A Challenge to Nigeria Security System

https:/ / thomotuyaben.files.wordpress.com/ 2013/ 01/ kidnapping.pdf

xxvi. Kidnapping and National Security in Nigeria https:/ / www.iiste.org/ Journals/ index.php/ RHSS/ article/ viewFile/ 11987/ 12311

xxvii. Kidnapping in Nigeria: An Emerging Social Crime and the Implications for the Labour Market http:/ / www.ijhssnet.com/ journals/ Vol-4-No-1-January-2014/ 15.pdf

xxviii. Kidnapping in Nigeria: causes and solutions https:/ / www.legit.ng/ 1135809-kidnapping-nigeria-solutions.html

xxix. Kidnapping in Pre- and Post-Amnesty Niger Delta, Nigeria http:/ / rcmss.com/2017/ IJPCS/ Kidnapping-in-Preand-Post-Amnesty-Niger-Delta-Nigeria.pdf

xxx. Kidnapping (Insecurity) and Nigerian Labour Market https:// researchcyber.com/kidnapping-insecurity-andnigerian-labor-market/

xxxi. Kidnapping in Nigeria the Latency of Kidnapping: The Nigerian Scenario https:/ / kidnappinginnigeria.blogspot.com/

xxxii. Kidnapping: Soldiers declare war in Abia

xxxiii. http:// allafrica.com/ stories/ 201010130500.html

xxxiv. Kidnapping: Understanding and managing the threat

xxxv. http:// www.homesecuritya.com/article.aspx?plclarticleid=2443

xxxvi. Insecurity in Nigeria Causes Effects Solution https:// researchcyber.com/insecurity-nigeria-causes-effectssolution/ National Security

xxxvii. htt:// en.wikipedia,org/ wiki/ national-security

xxxviii. Nigeria and the Menace of Kidnapping: The Way Forward http:/ / globalacademicgroup.com/ journals/ nigerian\%20journal\%20of\%20research\%20and\%20production\%2 0/ NIGERIA\%20AND\%20THE\%20MENACE\%200F\%20KIDNAPPING.pdf

xxxix. Pervasive kidnapping in Nigeria: Symptom of a failing state

xl. http:/ / www.hollerafrica.com/ showArticle.php?artld=3048catld=1

xli. Pew sine kidnapping in Nigeria: Symptom of a failing state http/ / :www.hollerafrica.com/ showArticle.php?artid=304\&cat/ d=1

xlii. Political and socioeconomic implications of kidnapping http:/ / www.nigerianbestforum.com/ index.php?topic=16881.0

xliii. Ransom https:/ / www.thefreedictionary.com/ ransom

xliv. Socioeconomichttps:// www.vocabulary.com/ dictionary/ socioeconomic

xlv. Socioeconomic Effects of Kidnapping in Nigeria https:// researchcyber.com/socioeconomic-effects-kidnappingnigeria/ The Lagos State Anti-kidnapping

xlvi. https:/ / guardian.ng/ opinion/ the-lagos-state-anti-kidnapping-law/ The strange political economy of kidnapping http:/ / econlog.econlib.org/ archieves/ 2010/ 06/ the-strangepol.html

xlvii. Understanding kidnapping http:// www.safetymedesimple.wordpress.com/ 2013/ 05/ 08/ understandingkidnapping/

xlviii. What is the difference between abduction and kidnapping? https:// www.quora.com/ What-is-the-differencebetween-abduction-and-kidnapping

xlix. Akpan N.S, (2010), Kidnapping in Nigeria's Niger Delta: An exploratory Study.Journal of Social Science, 24(1) 3342

1. Akpan, N .S, and Akpabio, E .M, (2009). Oil and Conflicts in the Niger Delta Region, Nigeria: Facing the Facts. Journal of Social Development in Africa, 24(1): 9-35.

li. Akpan, N. S, and Akpabio E.M, (2003). Youth Restiveness and Violence in the Niger Delta Region of Nigeria: Implications and Suggested Solutions. International Journal of Development Issues, 2(2): 37-58. CBN 1981 Annual Reports.,

lii. Ezeibe, C.C. and Eze, M.O. (2012). "Political economy of kidnapping in Nigeria - The South East Experience". Journal of Liberal Studies, 15 (1).

liii. Maicibi, N.A and Yahaya, S.A. (2013). "Criminal and unethical behaviours in organizations. Misuse of assets and false or misleading advertising”. Global Journal of Human Social Sciences (F): Political Science, 13 (3:1.0), pp. 1 10.

liv. Okoli, A.C. (2013). "The Political Ecology of the Niger Delta Crisis and the Prospects of Lasting Peace in the Post Amnesty Period". Global Journal of Human Social Sciences (F): Political Science, 15 (3:1.0), pp. 37 - 46.

lv. Okoli, A. C. and Orinya, S. (2013). "Oil Pipeline vandalism and Nigeria's national security". Global Journal of Human Social Sciences (F): Political Science, 13 (3:1.0), pp. 65 - 75.

lvi. Okoli, Al Chukwuma \& Agada, Fakumo T. Kidnapping And National Security In Nigeria Department of Political Science, Federal University Lafia, PMB 146, Lafia, Nigeria.

lvii. Email of the corresponding author:okochu007@yahoo.com [The World Fact book, U.S.C.I.A. 2009]

lviii. Riechery \& Roberg (1990). Community policing. In the Journal of Police science and Administration, vol., $17 \mathrm{pp}$ 107.

lix. Turner, M., (1998). Kidnapping and Politics; International Journal of the Sociology of Law, 26: 145-160

lx. BBC (2018), "Somali Gunmen Abduct German Red Cross Nurse in Mogadishu."

lxi. Briggs, Rachel (2009), The Kidnapping Business. Guide of Security Controllers Newsletter. 
lxii. Christie, Sam (2017), "'Truly despicable.' Who is Karen Matthews and why did she kidnap Shannon? UK's 'most hated mom' who abducted her own daughter," The Sun.

lxiii. Davidson, I. (2010) Nigeria: Stunting Economic Growth and Development in South East (This Day13 June 2010)

LXIV. Premium Times (2018), Dapchi Abduction: Yobe Governor Blames Nigeria Army for Abduction of Schoolgirlsby Premium Times February 25, 2018

LXV. The Economist (2017), "Who Kidnapped the Son of Slovakia's President?"United Nations publication "Freedom of the Individual under Law: an Analysis of At1icle 29 of the United Nations Declaration of Human Rights". Vanguard Newspaper, 13 August, 1999 P. 7.

lxvi. Vanguard on-line (2009). "Kidnapping: A crime against humanity. What is the way out?", June 22, 2009. Wogu, A., (2010) Nexus between Social Vices and Stunted Productivity, The Guardian Newspaper, July, pg37.

lxvii. Akambi Mustapha (2010), "Youth Unemployment in Nigeria, Causes, Consequences and Remedies: being paper delivered by The former Chairman, Independent Corrupt Practices and other Related Offences Commission (ICPC), Ilorin Kwara State; symposium, organised by AMICUS International Club Nov.22.

lxviii. Alemika, E.E.O. (2012). "Corruption and Insecurity in Nigeria”. In R.A Dunmoye, E.A. Unobe and A.R. Sanusi (eds.), Proceedings of the ABU@50 Humanities' International Conference. Zaria: Ahmadu Bello University Press Ltd, pp. 35-50.

lxix. Bamiduro, J, (2010), "Youth Unemployment in Nigeria, Causes, Consequences And Remedies: being paper delivered by The former Chairman, Independent Corrupt Practices and other Related Offences Commission (ICPC), Ilorin Kwara State; symposium, organised by AMICUS International Club Nov.22.

lxx. Okolo,S (2010) Security Challenge in South East and South South, being a speech delivered during south East and South South Security Summit organised by National Association of Chamber of Commerce, Industry, Mine and Agriculture (NACCIMA) in Enugu

lxxi. Onovo,O.,(2010) Security Challenge in South East and South South, being a speech delivered during south East and South-South Security Summit organised by National Association of Chamber of Commerce, Industry , Mine and Agriculture (NACCIMA) in Enugu

lxxii. Ugwuoke, C.U (2005). Restitution of crime victims in Nigeria: A study of Public Perception in Enugu State. PhD Thesis, Dept. of Sociology/ Anthropology, UNN. 